\title{
2. SEISMIC STRUCTURE OF THE VOLCANIC APRON NORTH OF GRAN CANARIA ${ }^{1}$
}

\author{
Thomas Funck ${ }^{2}$ and Holger Lykke-Andersen ${ }^{3}$
}

\begin{abstract}
High-resolution reflection seismic profiles through the volcanic apron north of Gran Canaria collected during Meteor Cruise 24 were interpreted in the light of results from Leg 157 (Sites 953 and 954). The shape of the submarine island flanks of Gran Canaria and the two adjacent islands of Fuerteventura to the east and Tenerife to the west were reconstructed by interpretating seismic profiles that penetrated the sediments covering the deeper portions of the volcanic pedestals. The $\sim 4750$-m-deep flank of Fuerteventura is the oldest submarine island flank, influencing the subsequent shield-building of Gran Canaria to the east, whose 16- to 15-Ma shield is ponded against Fuerteventura, forming a topographic barrier between the islands. The associated reduction of the current cross section has caused strong bottom currents, indicated by erosional features and contourites. To the north, the flank of Gran Canaria extends $60 \mathrm{~km}$ seaward to a depth of $\sim 4500 \mathrm{~m}$. The shield of the Anaga massif on northeast Tenerife onlaps the flank of Gran Canaria to the east. Seismic correlation of the feathered edge of the Anaga shield $(\sim 50$ $\mathrm{km}$ off Tenerife at a depth of $4000 \mathrm{~m}$ ) to the bio- and magnetostratigraphy at Site 953 results in an age of $\sim 6 \mathrm{Ma}$.

The surrounding sedimentary basin is characterized by chaotic and discontinuous reflection patterns of the slope facies, turning into well-stratified basin facies $\sim 30-40 \mathrm{~km}$ off the coast. The westward decrease of reflectivity in the northern apron is interpreted to be caused by the submarine ridge off Galdar at the western limit of the north coast of Gran Canaria, through which mass flows from Gran Canaria entering the sea in the north were diverted to the northeastern part of the apron. The volcanic activity correlates with the sedimentation rates in the apron. The lowest rate corresponds to the volcanic hiatus on Gran Canaria (9-5 Ma) with 3-4 cm/k.y., and the highest rate (up to $12 \mathrm{~cm} / \mathrm{k} . \mathrm{y}$.) was found during the voluminous Miocene volcanism on the island. A number of large mass-wasting events could be identified, interbedded with the pelagic background sedimentation. The basaltic breccia drilled at Site 954 (lithologic Unit IV) is interpreted to represent the deposits associated with a slope failure at the northern flank of Gran Canaria at $12 \mathrm{Ma}$. The seismic mapping reveals $>60 \mathrm{~km}^{3}$ of debris advanced at least $70 \mathrm{~km}$ into the apron. The volume fits well with the dimensions of an amphitheater at the northern flank of Gran Canaria. The Quaternary volcanism on La Isleta at northeast Gran Canaria extends further seaward, where the seismic data show young lava flows. Other submarine volcanism occurred in the channel between Gran Canaria and Fuerteventura.
\end{abstract}

\section{INTRODUCTION}

The Canarian Archipelago is built on the African continental slope and rise and extends $450 \mathrm{~km}$ from east to west (Fig. 1). The volcanic aprons surrounding the islands consist of material derived through volcanic activity, slides, and erosion on the islands, intercalated to the background sedimentation. The aprons south of the Canary Islands contain slumped material from the African continental margin (von Rad, Ryan, et al., 1979; Schmincke, Weaver, Firth, et al., 1995), contrasting the northern basin, which is shielded from such influx by the East Canary Ridge (Fuerteventura, Lanzarote, and Conception Bank), forming a morphological barrier. The sedimentary basin north of the Canary Islands extends $\sim 200 \mathrm{~km}$ up to the Selvagem Islands, corresponding to the lateral extent of the moat because of the load of the Canary Islands (Watts, 1994).

High-resolution seismic reflection data collected during Meteor Cruise 24 over the northern apron of Gran Canaria (Fig. 2) offer the opportunity to extrapolate the one-dimensional drilling results at Sites 953 and 954 across the apron up to a distance of $100 \mathrm{~km}$ from the shore. Correlation with the bio- and magnetostratigraphy at the drill sites was obtained by synthetic seismograms that were matched to the observed seismic data (Funck and Lykke-Andersen, Chap. 1, this volume; Funck, 1996).

The aim of this study was to analyze the structure of the volcanic apron north of Gran Canaria, whose volcaniclastic deposits contain a

${ }^{1}$ Weaver, P.P.E., Schmincke, H.-U., Firth, J.V., and Duffield, W. (Eds.), 1998. Proc. ODP, Sci. Results, 157: College Station, TX (Ocean Drilling Program).

${ }^{2}$ Graduiertenkolleg, GEOMAR, Wischhofstraße 1-3, 24148 Kiel, Federal Republic of Germany (Present address: Department of Oceanography, Dalhousie University, Halifax, Nova Scotia, B3H 4J1, Canada. tfunck@is.dal.ca). Denmark. record of the evolution of Gran Canaria and the two neighboring islands, Fuerteventura and Tenerife. The goal was to broaden the knowledge about the volcanic evolution of these islands, to determine their submarine dimensions, to study how the volcanism and erosion is reflected in the surrounding sediments, and to detect large mass-wasting events associated with the destruction of the islands.

\section{GEOLOGICAL SETTING}

The island group of the Canaries is located between magnetic anomalies M21 (148 Ma) and S1 (Fig. 1). Roest et al. (1992) interpret the anomaly S1 as true oceanic crust, and Klitgord and Schouten (1986) date the anomaly at $175 \mathrm{Ma}$. The location of S1 coincides with the seaward extent of a series of salt diapirs, marking the approximate landward edge of oceanic crust (Hinz et al., 1982).

The Canary Island volcanism is much younger than the underlying oceanic crust. The earliest submarine volcanics are Late Cretaceous to early Tertiary (Le Bas et al., 1986). The oldest subaerial volcanic activity occurred on Fuerteventura (20 Ma; Coello et al., 1992), whereas the westernmost island Hierro is as young as $1 \mathrm{Ma}$ (Fúster et al., 1993). The volcanic apron north of Gran Canaria also represents the deposition area for volcaniclastic material from the two neighboring islands, Tenerife and Fuerteventura. The volcanic activity of these three islands is therefore briefly summarized below.

Three major magmatic/volcanic cycles have been distinguished on Gran Canaria, and these have been further subdivided into several stages (Schmincke, 1976, 1982, 1994; Hoernle and Schmincke, 1993a, 1993b). All subaerially exposed volcanic and intrusive rocks were formed during the last 15 m.y. (McDougall and Schmincke, 1977). The subaerial Miocene Cycle, with rapid formation (0.5 Ma) of the shield basalts, was followed by magmatism of the Mogan phase (14.1-13.5 Ma) and the Fataga phase ( 13-9.5 Ma). The Mio-

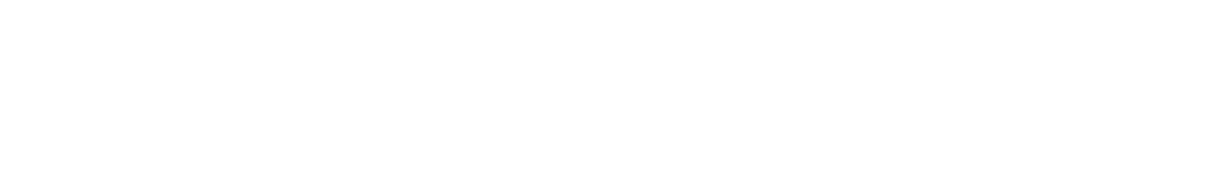


Figure 1. Location map of Sites 953 through 956 (Leg 157) and Site 397 (Leg 47) in the vicinity of the Canary Islands shown together with the magnetic anomalies (Verhoef et al., 1991) and the limits of the salt diapir zone between the eastern Canaries and Africa (Hinz et al., 1982). The square box is the study area (Fig. 2). Bathymetric contour interval is $1000 \mathrm{~m}$.
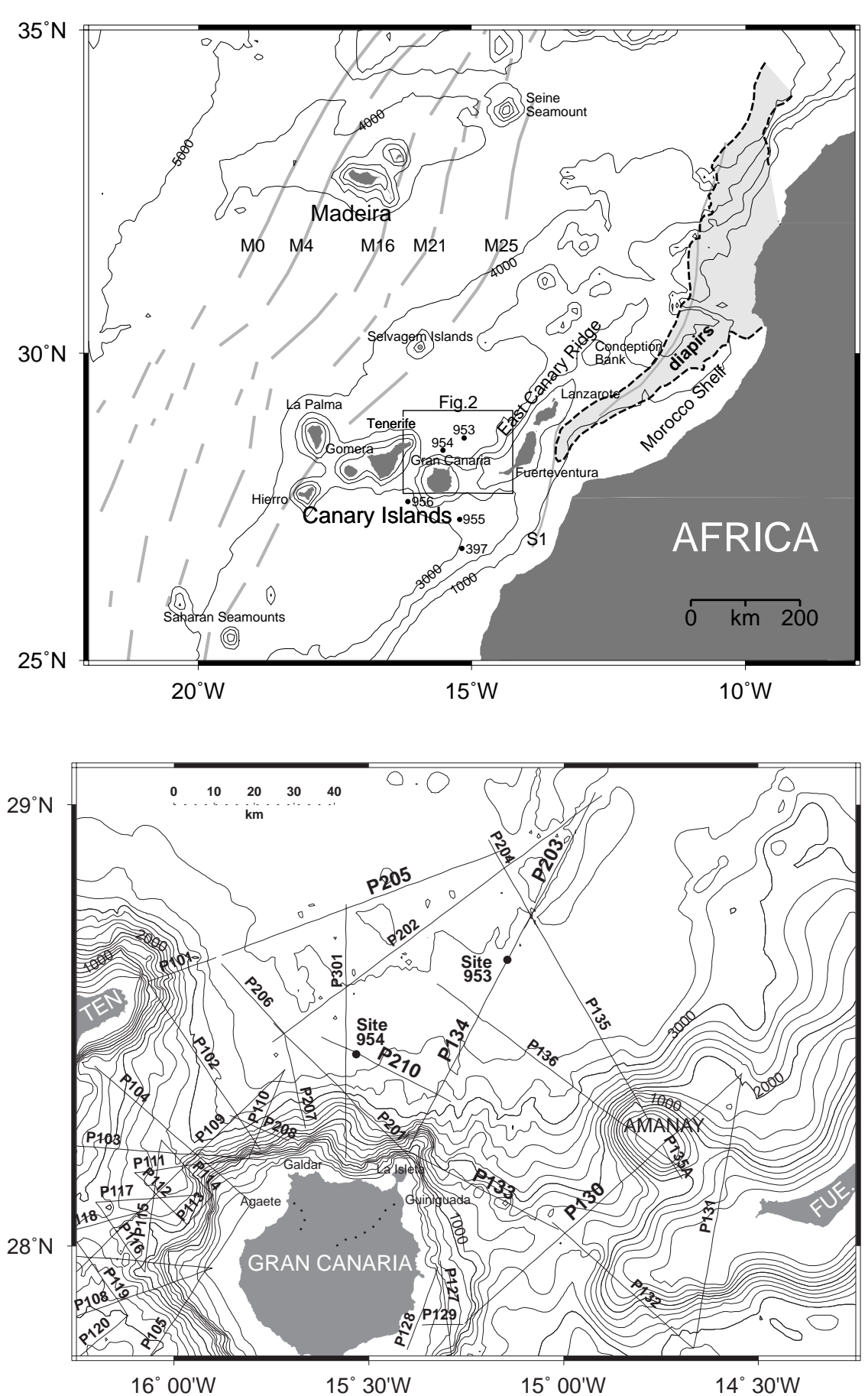

Figure 2. Study area with location of the reflection seismic profiles of Meteor Cruise 24. Bathymetric contour interval is $200 \mathrm{~m}$. The dotted lines on Gran Canaria show the location of the canyons Barranco de Agaete and Barranco de Guiniguada $($ TEN. $=$ Tenerife, and FUE. $=$ Fuerteventura).

cene Cycle was followed by a major volcanic hiatus until the Pliocene Cycle, which began at $\sim 5 \mathrm{Ma}$, with peak activity $\sim 4 \mathrm{Ma}$ (Roque Nublo Group). The bulk of the Roque Nublo volcanics was deposited in the northern half of the island. Quaternary volcanism occurred exclusively in the northern part of Gran Canaria.

Two major formations can be distinguished on Fuerteventura: an emerged basal complex and a younger subaerial volcanic series (Coello et al., 1992). The submarine volcanics of the basal complex are as old as $48 \mathrm{Ma}$ (Le Bas et al., 1986). The subaerial shield basalts were formed by three independent edifices (Coello et al., 1992): (1) the southern edifice - closest to our seismic net—with main activity between 16 and $14 \mathrm{Ma}$; (2) the central edifice, with three eruptive cycles between $\sim 20$ and $17 \mathrm{Ma}$, and, $\sim 15$ and $13 \mathrm{Ma}$; and (3) the northern edifice, where main activity occurred between 14 and 12 Ma. A major temporal gap separates these basalts from the postMiocene volcanic activity ( $<5 \mathrm{Ma})$ in the central and northern regions.

The oldest visible unit on Tenerife is that of the shield basalts (Anaga, Teno, and Roque del Conde massifs; Ancochea et al., 1990). The Anaga massif in the northeast, adjacent to the investigated apron, was formed between 6.5 and $3.6 \mathrm{Ma}$, with major activity occurring between 6 and $4.5 \mathrm{Ma}$. Voluminous Quaternary volcanic activity on Tenerife was concentrated in the center of the island (Cañadas volcano, 1.9-0.2 Ma) and to a chain of basaltic eruption centers from the central volcano to the northeast (Cordillera Dorsal, peak activity $\sim 0.8$ Ma). 


\section{SEISMIC REFLECTION DATA}

\section{Data Acquisition}

Meteor Cruise No. 24 in April and May 1993 (Schmincke and Rihm, 1994) was the main presite survey for Leg 157. A total of 2117 $\mathrm{km}$ of high-resolution reflection seismic data were recorded along 50 profiles around the entire island of Gran Canaria. Some of the seismic data were already interpreted without knowledge of the drilling data in a more general overview by Funck et al. (1996). For the purpose of this paper, the lines north of Gran Canaria and in the northern part of the channel toward Fuerteventura were studied in detail (Fig. 2).

The seismic source was a sleevegun cluster consisting of four guns with a volume of $0.65 \mathrm{~L}$ each. Bubble oscillations were effectively suppressed by the narrow gun clustering of $0.5 \mathrm{~m}$, increasing the signal to noise ratio. The signal was recorded by means of a "24channel" streamer, with a group spacing of $6.25 \mathrm{~m}$ resulting in a total length of $143.75 \mathrm{~m}$. The data were bandpass-filtered $(20-360 \mathrm{~Hz})$ and sampled at $1-\mathrm{ms}$ intervals. The firing rate was chosen depending on the water depth to maximize the shot frequency and thereby get a maximum fold of stack. The firing rates of $5,7.5$, and $10 \mathrm{~s}$ correspond to a nominal shotpoint distance of $12.5,18.75$, and $25 \mathrm{~m}$, respectively, with a ship speed of $2.5 \mathrm{~m} / \mathrm{s}$.

\section{Data Processing}

The prestack processing of the seismic data was carried out at the University of Århus, Denmark. Because of the great water depth and the short streamer length, no intensive velocity analysis was possible. The goal of the following processing at GEOMAR, Kiel, Germany, was to obtain time-migrated sections. A migration velocity analysis was carried out to get a velocity model along the seismic line, serving as input for the final finite-difference migration in the time-space (tx) domain or in the frequency-space ( $\mathrm{fx}$ ) domain. Before migration, the data were resampled from 1 to $2 \mathrm{~ms}$, because the amplitude spectra showed that the seismic energy lies between 20 and $240 \mathrm{~Hz}$. In the horizontally layered parts of the profiles, usually two or four common midpoint (CMP) traces were stacked together to enhance the signal to noise ratio. Both processes reduced the central processing unit time necessary for migration.

Because the island flanks are characterized by a rough morphology, some energy is reflected and diffracted from structures out of the plane of the profile. Such three-dimensional features cannot be treated properly with the applied two-dimensional migration, and hence, remnants of these side echoes are occasionally visible. Finally, timevariant frequency filtering was applied. The display of the lines in Figures 3-10 is with Automatic Gain Control (window length 50$200 \mathrm{~ms}$ ).

\section{SEISMIC STRUCTURE OF THE APRON}

To gain a detailed insight into the structure of the volcanic apron north of Gran Canaria, a set of characteristic seismic lines are described below and a summary of the two drill sites in this area (Sites 953 and 954) is also given. The location of the profiles and drill sites is shown in Figure 2.

\section{Site 953}

The sedimentary sequence at Site 953 ranges in age from middle Miocene to Holocene and is $1159 \mathrm{~m}$ thick (Schmincke, Weaver, Firth, et al., 1995). The sequence is subdivided into seven lithologic units (Fig. 3). Unit VII (1159-969 meters below seafloor [mbsf]) consists entirely of early Miocene hyaloclastite tuffs, lapillistones, and breccias, probably formed by a shallow submarine eruption of basaltic magma. Unit VI (969-889 mbsf) consists largely of thick- bedded basaltic sandstone, lapillistone, and breccia. It represents the outermost flank of the shield volcano of Gran Canaria, comprising deposits of both subaerial and shallow submarine volcanism. The emplacement of material occurred through debris flows and turbidity currents. Lithologic Units V through I (889-0 mbsf) represent pelagic sediments with interbedded volcaniclastic layers emplaced by gravity flow processes (turbidites) and eolian transport.

The vertical seismic facies changes in the vicinity of Site 953 have been used to distinguish seven seismic units (Units 1-7) in the sediments above the island flank, which are not identical with the lithologic units. Reflectors at the base or close to the base of prominent reflector bands showing a good correlation in the apron serve to define boundaries between the seismic units. These reflectors are called M (13.9 Ma, deposited during Mogan phase of volcanism), F (11.8 Ma, deposited during Fataga phase of volcanism, H (9.5 Ma, deposited during the transition from the Fataga phase to the large Miocene hiatus of volcanism on Gran Canaria), T (5.3 Ma, deposited during the shield stage of Tenerife), RN (3.6 Ma, deposited during the Pliocene Roque Nublo phase), and Q (0.8 Ma, Quaternary deposit) (Fig. 3; see also Funck and Lykke-Andersen, Chap. 1, this volume).

\section{Line 134}

Line 134 (Fig. 4) is located radial to Gran Canaria in a southsouthwest-north-northeast direction (Fig. 2). Its southern end is 3.5 $\mathrm{km}$ away from La Isleta peninsula, which is characterized by Quaternary volcanism (Schmincke, 1994). The division into several facies units can be recognized on this profile. Following the definition of Schmincke (1994), a volcanic apron peripheral to an oceanic island consists of three main facies:

1. The core or flank facies is characterized by rough topography and discontinuous reflectors (chaotic seismic facies; Wissmann [1979] and Holik and Rabinowitz [1991] have used the term "volcanic apron" exclusively for this facies).

2. The proximal or slope facies is characterized by slumps, discontinuous bedded units, debris flows, and erosional channels, and so forth.

3. The slope facies grades laterally into the basin facies, which is characterized by well-developed reflectors and groups of reflectors and consists of diverse types of volcaniclastic deposits including fallout ash layers, debris flows, distal ignimbrites and lahars, and other volcaniclastic rocks generated by eruptions and erosion of volcanic rocks.

The volcaniclastic deposits are interbedded with biogenic and/or siliciclastic terrigeneous sediments forming the background sedimentation to the volcaniclastic influx from the islands.

The flank facies comprising the volcanic edifice is characterized by steep flanks up to a dip of $32^{\circ}$ close to Gran Canaria on Profile 134 (Fig. 4). Toward the basin, the dip decreases to $0.5^{\circ}$ close to the feathered edge of the volcanic edifice. The flat flank is defined by a high amplitude, long-period reflector with a discontinuous mounded structure.

The southernmost volcanic edifice on Line 134 is formed by two volcanic cones, which seem to represent the offshore continuation of the volcanism on La Isleta. The cone at CMP 1000 is the starting point for three radial ridges interpreted as lava flows (Funck, 1996), two of which are crossed by the seismic line (between CMP 1700 and 4800 ). Both lava flows are almost reflection-free and downlap onto the seafloor. They are therefore very recent features $(<<1 \mathrm{Ma})$ indicating ongoing volcanism at the La Isleta submarine complex.

On a large scale, the entire sedimentary sequence shows infill characteristics with onlap onto the flank of Gran Canaria. The slope facies is characterized by chaotic patterns in the lower third of the sequence above the volcanic shield, succeeded by relatively regular stacks of mounded structures in the upper part. Outside the slope 


\section{Seismic Site 953 Lithologic unit M24-Line 134 unit}

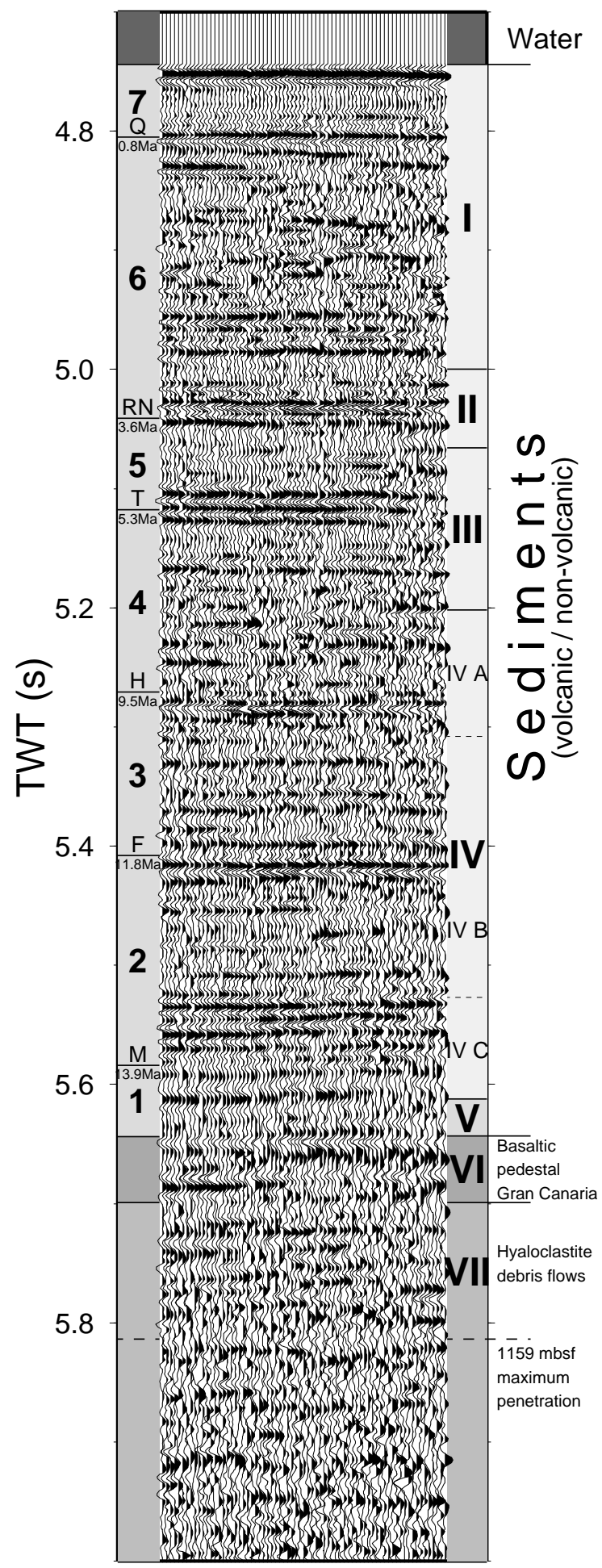

Figure 3. A 220-m-wide stacked portion of seismic Line 134 around Site 953. The right column shows the division in lithologic units and subunits (I through VII) and the left side the division in seismic units (7 through 1), along with the names of prominent reflector bands. Small numbers below the reflector names give the age in Ma (Funck and Lykke-Andersen, Chap. 1, this volume). V.E. = vertical exaggeration. facies, which extends some $40 \mathrm{~km}$ from Gran Canaria, the seismic facies changes to a more regular basin-fill facies with parallel or basinward diverging reflectors. Individual reflectors can be correlated within the slope facies, where the correlation gradually decreases by a transition into more complex patterns.

Further seaward, the reflections become almost horizontal above reflector $\mathbf{M}$. Below reflector $\mathbf{M}$, there is a small islandward dip $\left(<0.5^{\circ}\right)$. Reflections below the island flank are discontinuous, and the amplitude decreases with the thickening of the volcanic pedestal. Toward the south-southwest, the dip of these reflectors becomes again more or less horizontal, but this is probably because of a pull up effect caused by the thickening of the high velocity shield on the time section. Beneath the voclanic shield at Site 953, thick hyaloclastite debris flows with several internal reflectors were found (lithologic Unit VII). The internal reflectors are caused by variations in the composition of individual debris flows and they can be correlated toward Fuerteventura, where they onlap onto the flank of the Amanay Bank.

The thickening of the transparent facies below reflector RN toward the north indicates a decreasing depositional energy for the period 4.9-3.6 Ma, with a reduced volcaniclastic sediment supply in the distal area of Gran Canaria.

An erosional channel with truncations at both flanking walls is located between CMP 6900 and 9400 . The channel is crossed obliquely, its true width is $\sim 3.5 \mathrm{~km}$, and it is cut $\sim 200 \mathrm{~m}$ into sediments. In the upper $150 \mathrm{~ms}$ two-way traveltime (TWT) below the channel bed, several unconformities were identified, forming lows that were subsequently filled again by sediments. This indicates complex interaction between erosion and sedimentation in the channel. Analysis of these patterns and correlation toward Site 953 results in the estimation that erosional processes have been active since at least $5 \mathrm{Ma}$.

\section{Line 203}

Line 203 (Fig. 5) is the seaward continuation of Profile 134 (Fig. 2 ). The line shows a well-stratified sedimentary basin with two striking features.

At the northeastern end of the profile, two domal uplift structures are seen, updoming the overlying strata up to the lower half of seismic Unit 6 and possibly piercing layers at deeper levels. The 13.9million-year-old reflector band $\mathrm{M}$ forms a $30 \mathrm{~ms}$, TWT, deep rim syncline, a feature that is usually associated with diapirism. The initial uplift therefore must have taken place around that time. The origin of the uplift is discussed in Funck et al. (1996). Gravity and magnetic data, as well as the occurrence of a rim syncline, exclude a magmatic origin. The remaining possibilities comprise mud or salt diapirism. In the case of a salt structure, one has to explain the origin of the salt. Hinz et al. (1982) have mapped a north-northwest-southsoutheast trending zone of salt diapirs east of Fuerteventura (Fig. 1). The western limit of this zone roughly coincides with the limit of the flank of Fuerteventura mapped by Wissmann (1979). Possible salt diapirs beneath Fuerteventura would be seismically masked by the overlying volcanic basement, and hence, the salt deposits may well extend further to the west. On the other hand, mud diapirism involves mud and overpressured multiphase pore fluids (water and methane; Brown, 1990). At Site 953, closest to the uplift structures, the methane concentration is below 34 ppm (Schmincke, Weaver, Firth, et al., 1995), whereas values of up to 54,965 ppm were recorded at Site 955. The same is true for Deep Sea Drilling Project Site 397 (Whelan, 1979). In summary, the methane content can change over short distances, and considerable concentrations can occur locally. Sediments close to the continental margin have especially high methane content, suggesting a relation to the sediment supply from the continent. A high methane content in the deep northern basin below the drilling penetration thus is conceivable, as there are sediments that were deposited before the buildup of the topographic barrier of the Eastern Canary Islands, which protects the area from sediment supply from Africa. 

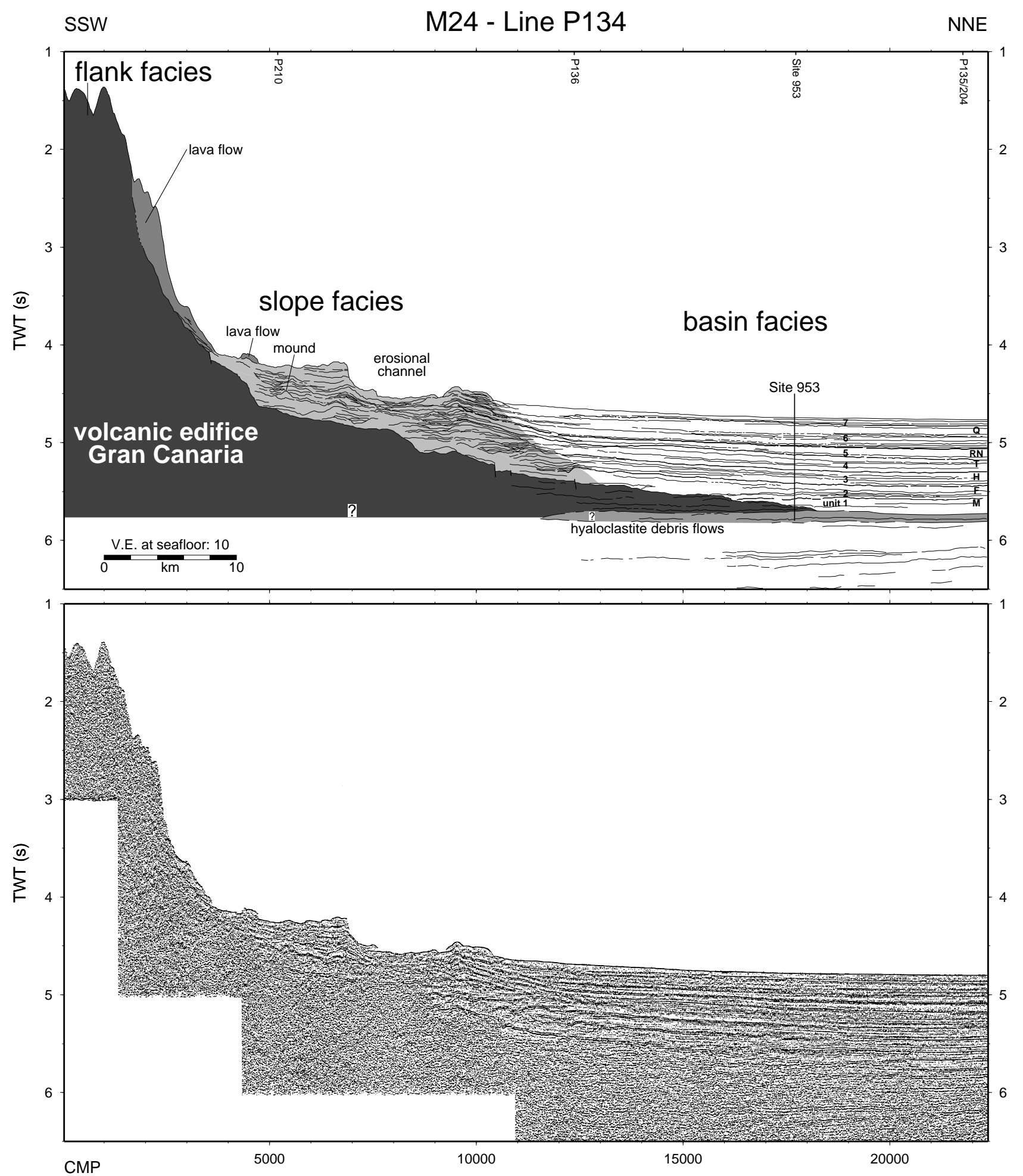

Figure 4. Time-migrated seismic section and line drawing for Line 134, radial to Gran Canaria, showing the division into different apron facies and the location of Site 953. Line location is shown in Figure 2. CMP = common midpoint, corresponding to $3.125 \mathrm{~m}$.

The second interesting feature on this profile is reflector band $\mathrm{M}$, representing an unconformity with almost horizontal strata above and south-southwest dipping reflectors below. Several onlap terminations onto the reflector band can be seen. The dip of the reflectors below reflector $\mathrm{M}$ is $\sim 0.3^{\circ}$. The formation of Gran Canaria is thought to be responsible for the subsidence of the originally horizontally lay- ered sediments below reflector M. Subsequent to the rapid shieldbuilding phase of the island, the underlying lithosphere has responded to the volcanic load by flexure (Funck et al., 1996). The related moat was later filled by horizontally layered sediments. Watts et al. (1997) show a similar flexure on their reflection seismic profile around Tenerife. 


\section{SsW M24 - Line P203 NNE}
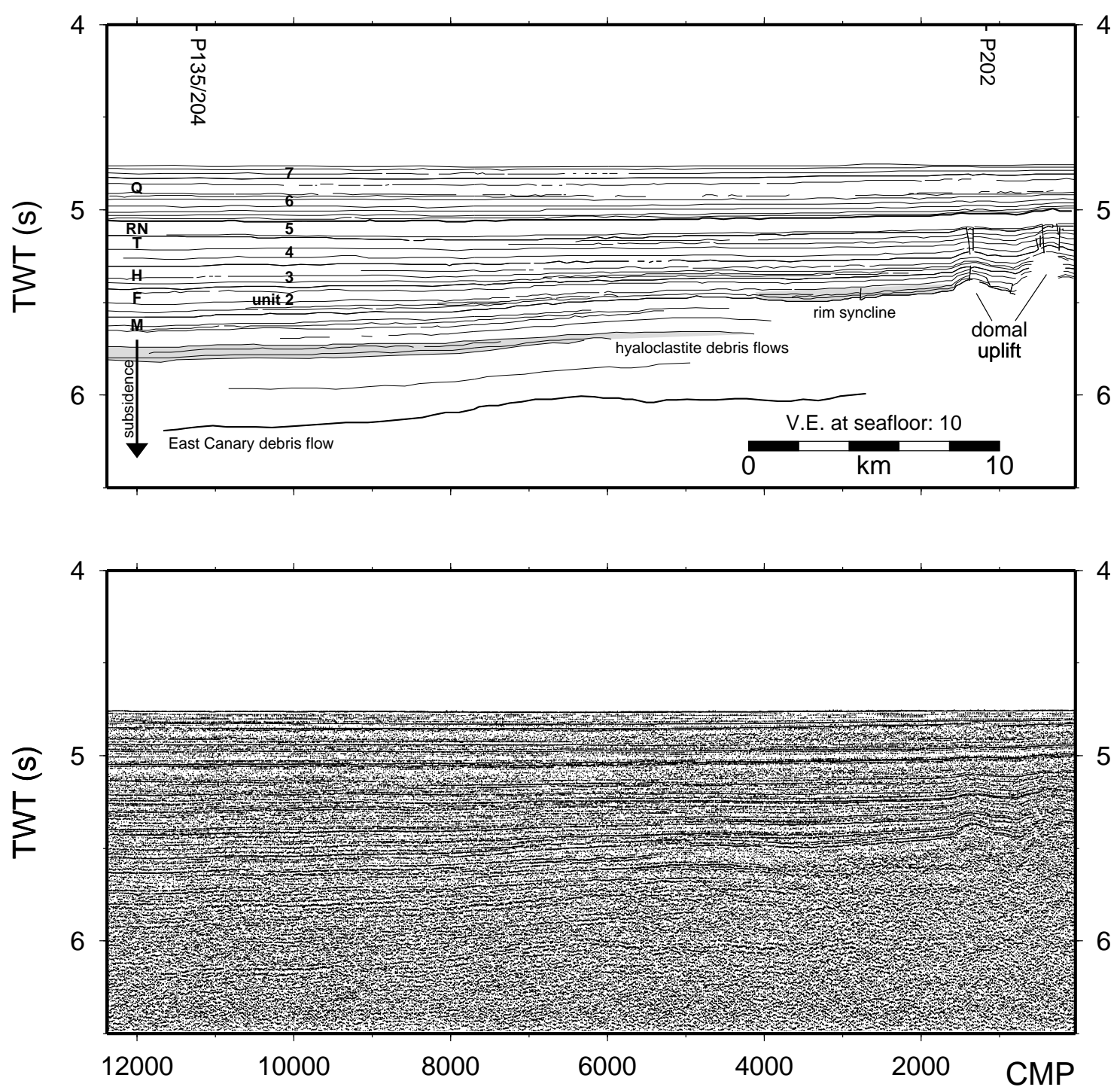

Figure 5. Time-migrated seismic section and line drawing for Line 203. Location is shown in Figure 2.

The hyaloclastite unit of Site 953 (lithologic Unit VII) can be correlated up to CMP 4000, where the otherwise high amplitudes decrease and the unit thins out. The last point to mention on this line is the prominent reflector band in the lower portion of the profile. In the northeast, its depth is $\sim 6 \mathrm{~s}$, and in the southeast $6.2 \mathrm{~s}$, following the general dip of the reflectors below reflector band M. Identification of this reflector on Lines 202 and 205 shows a westward decrease in the thickness of the unit, and a source in the east can be assumed. Deposition was before the shield phase of Gran Canaria, and hence, this may be a volcaniclastic debris flow from the early buildup of the East Canary islands of Fuerteventura and Lanzarote.

\section{Site 954}

The sedimentary succession drilled at Site 954 (Fig. 6) is $446 \mathrm{~m}$ thick and is subdivided into four lithologic units (Schmincke, Weaver, Firth, et al., 1995): Units I through III (0-408 mbsf) are Pleistocene to late Miocene in age and consist of pelagic sediments with volcaniclastic interbeds deposited by gravity flows. Unit IV (408-446 mbsf) is middle Miocene in age ( 14 Ma) and comprises exclusively basaltic breccia. It is separated from Unit III by a hiatus ( 10.7-14 Ma). The breccia are a mixture of subaerially derived and shallow-water volcanics, which typically occur during the emergent phase of volcanic islands.

On the JOIDES Resolution, Unit IV was interpreted to represent the island flank of Gran Canaria, and the hiatus was explained by removal of the missing sediments because of slumping (Schmincke, Weaver, Firth, et al., 1995). The detailed analysis of the seismic data after the cruise, however, suggests an alternative explanation, which is presented below in the description of Line 210.

By means of a synthetic seismogram, Funck (1996) correlated some of the reflectors with the lithology at Site 954. Lithologic Unit II (a 2-m-thick lapillistone unit) corresponds to the strong reflector band $\sim 4850$ ms TWT (Fig. 6), representing reflector RN (3.6 Ma). The second prominent reflector band $\sim 4740 \mathrm{~ms}$ is also caused by a lapillistone interbed (80.2 mbsf; Core 157-954B-1R). 


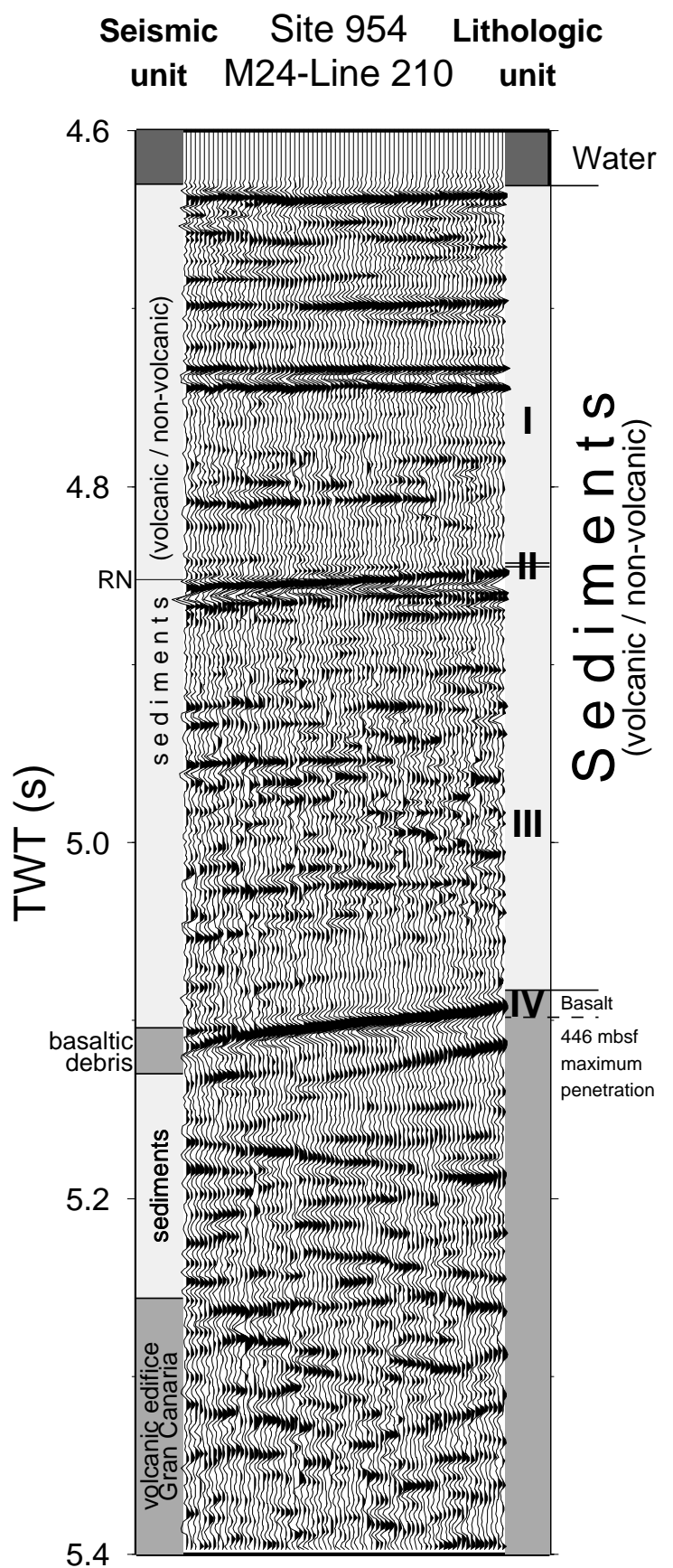

Figure 6. A 220-m-wide stacked portion of seismic Line 210 around Site 954. The right column shows the division in lithologic units (I through IV) and the left side the seismic interpretation. Correlation between the seismic data and the lithology was achieved by synthetic seismograms (Funck, 1996).

\section{Line 210}

The orientation of Line 210 (Fig. 7) is northwest-southeast, which is roughly tangential to Gran Canaria (Fig. 2). This orientation, perpendicular to the dip of the island flank with reflections from out of the plane of the line, is responsible for the diffuse patterns of this section. Amplitude and continuity of the basement reflector (top of volcanic shield) are considerably lower than on the two crossing radial
Lines 134 and 301. The flank has a mounded structure, and its depth increases toward the northwest as the distance from the island increases.

The sedimentary fill shows a gradual change from slope facies in the southeast to a transition zone between slope and basin facies in the northwest. The chaotic patterns in the southeast (between CMP 6000 and 12000) are probably intensified by numerous side echos. The frequent mounded structures with a width of 1 to $2 \mathrm{~km}$ indicate the significance of radial slides and debris flows for the construction of the sediment unit.

Below reflector band Q several toplap terminations of low amplitude reflectors indicate a period of erosion or nondeposition. This fits with the observed hiatus at $\sim 80 \mathrm{mbsf}$ at Site 954 (Schmincke, Weaver, Firth, et al., 1995).

The most interesting feature on Line 210 is lithologic Unit IV drilled at Site 954 (see above and Fig. 6). In the seismic data this unit is seen as a mounded, high-amplitude reflector (HAR) band. The unit is interpreted as a debris flow and onlaps onto the island flank at CMP 5200. West of CMP 1500, the amplitudes weaken. Between the debris flow and the island flank several hummocky, discontinuous reflectors are visible, representing sediments overridden by the debris flow. The age of the debris flow is slightly older than $12 \mathrm{Ma}$, inferred from the strata in which the unit is interbedded and which can be correlated toward Site 953. At first glance, this contradicts the age of 14 Ma of the foraminifers found in the unit; because the island flank lies below the debris flow, lithologic Unit IV may represent 14 m.y.-old material of the basaltic island flank of Gran Canaria, which was deposited at Site 954 by a large mass-wasting event at $12 \mathrm{Ma}$. The reported hiatus between lithologic Units III and IV therefore did not last from 14 to $10.7 \mathrm{Ma}$, but from 12 to $10.7 \mathrm{Ma}$. The reason for the hiatus can be seen in the location of the drill site, at the top of a mound formed by Unit IV. The surrounding strata show onlap terminations onto the mound until 10.7 Ma, when the sediments covered the top of the mound, indicating that the hiatus at Site 954 was finished.

\section{Line 205}

Line 205 (Fig. 8) is radial to the northeastern tip of Tenerife (Anaga massif) and crosses the entire apron north of Gran Canaria at a distance of $\sim 60 \mathrm{~km}$ from the shore (Fig. 2). The flank of Tenerife shows HARs with a good continuity. The slope of the flank decreases seaward and is almost horizontal at CMP 19200, where the reflection from the shield fades out ( $\sim 50 \mathrm{~km}$ northeast of Tenerife). The determination of the stratigraphic position of the feathered edge of the shield in the basin is hampered by the low reflectivity in the western part of the line. Nevertheless, the parallel and almost horizontal bedding in the basin allows for a good estimate of the age of the flank, which is $\sim 6 \mathrm{Ma}$. The maximum K-Ar dates given by Ancochea et al. (1990) are 5.7 Ma for the eastern part of the subaerial Anaga massif and 6.5 Ma for the western part, which is further away from the seismic line. Rapid growth of the submarine shield of Anaga is indicated by the fact that there is no discernible age difference between the submarine and subaerial portions.

At first glance, the sedimentary basin shows a very uniform pattern with a number of horizontal reflectors outside the flank area of Tenerife. When examined in more detail, the lateral changes are significant and allow some conclusions on the origin of the deposits. The most important lateral change is the general westward decrease of reflectivity in the sedimentary sequence, starting between $\sim$ CMP 6000 and 8000 . This is a general feature in the apron north of Gran Canaria and can be correlated toward a submarine ridge north of Galdar at the northern flank of Gran Canaria (Fig. 2). The westward decrease of reflectivity is therefore interpreted as caused by the influence of the Galdar Ridge on the sedimentation paths of volcaniclastics entering the sea at the northern flank of Gran Canaria. Reflectors affected by this systematic westward decrease are interpreted to have originated 

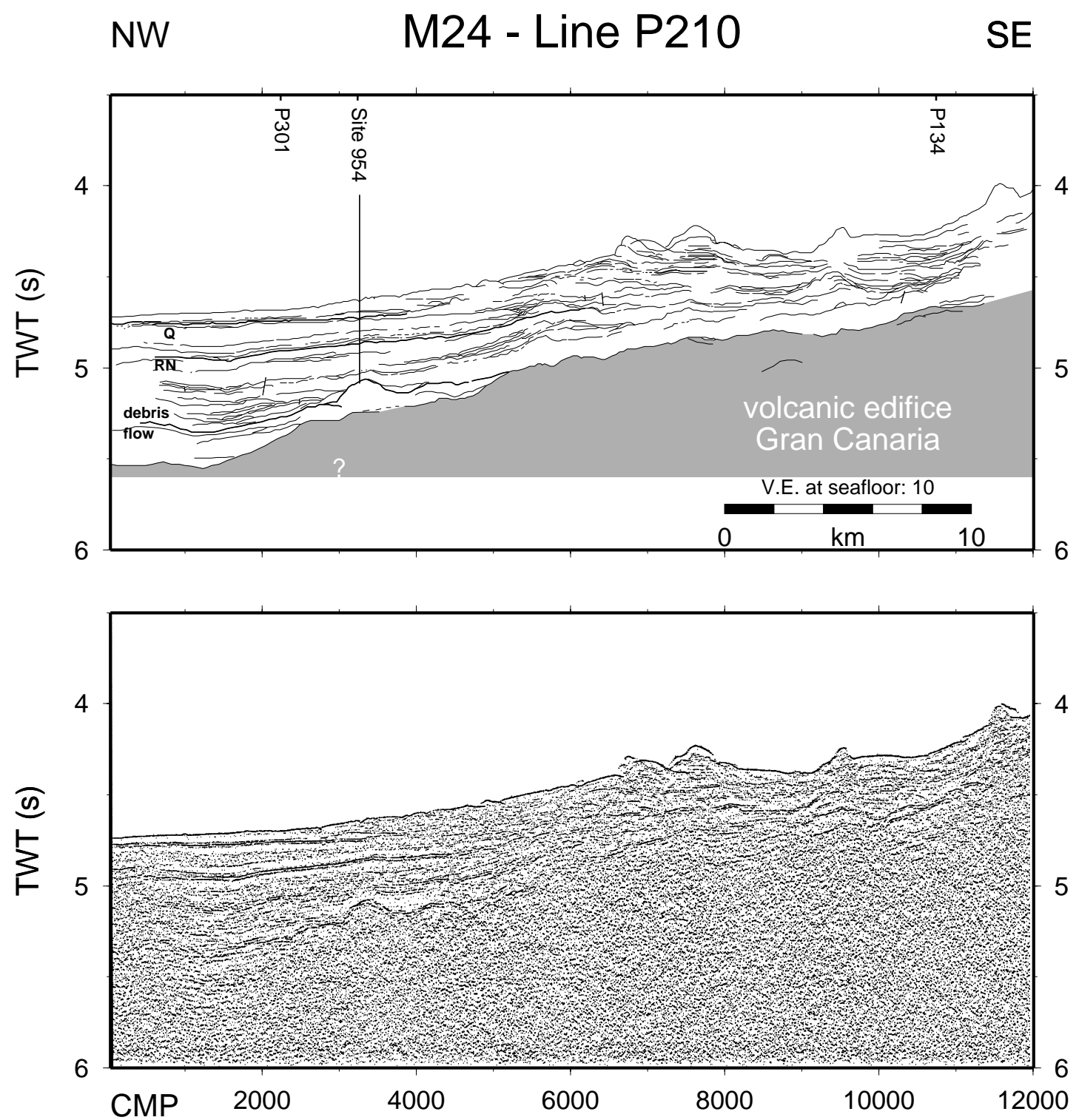

Figure 7. Time-migrated seismic section and line drawing for Line 210, showing the location of Site 954, $30 \mathrm{~km}$ north of Gran Canaria. Line location is shown in Figure 2.

from Gran Canaria. These patterns are visible between reflector bands $\mathrm{Q}$ and $\mathrm{F}$, with reflector $\mathrm{RN}$ as the main exception. Reflector $\mathrm{RN}$ is the most prominent reflector in the apron and can be correlated across almost the entire northern survey area. It is formed by lapillistones of the voluminous Pliocene Roque Nublo volcanism on Gran Canaria, which is probably responsible for those sedimentation paths not affected by the Galdar Ridge. The power of the Roque Nublo volcanism is emphasized by the height of the Roque Nublo volcano, which was built on the deeply eroded Miocene volcanic edifice and exceeded $>3000 \mathrm{~m}$ above sea level (Mehl, 1993; García Cacho et al., 1994). Today, the highest peak on Gran Canaria is $1949 \mathrm{~m}$, illustrating the amount of erosion.

The uppermost seismic unit between the seafloor and reflector Q (seismic Unit 7) is composed of volcaniclastics from both Gran Canaria and Tenerife. Northeast of CMP 9000, a number of horizontal reflectors occur with low to medium amplitudes, a narrow cycle breadth, and excellent continuity. These reflectors are interpreted to be caused by the coarse beach sands found at Sites 953 and 954
(Schmincke, Weaver, Firth, et al., 1995). The increase of their grain size toward Gran Canaria and the westward fading of the reflectors suggest a source on Gran Canaria. Input from Tenerife can be identified in three debris flows with downlap onto the seafloor at CMP 25000,23500 , and 9000. Thicknesses of these flows are $\sim 20,7$, and $10 \mathrm{~m}$, respectively. The reflector band $\mathrm{Q}$ itself shows a change of reflection patterns between CMP 16000 and 11200, where amplitudes and continuity decrease. This disturbance may be caused by currents radial to the profile as the disturbed area represents the approximate continuation of the deepest part of the channel between Gran Canaria and Tenerife.

At a depth of $5550 \mathrm{~ms}$ TWT, a conspicuous parallel reflector band can be seen between CMP 17500 and 10500 . This HAR band is characterized by good continuity, abrupt disappearance in the northeast, and gradual thinning southwest of CMP 16000 . The reflector band corresponds to the basaltic debris flow drilled as lithologic Unit IV at Site 954, constraining the northward extent of the flows, $>70 \mathrm{~km}$ away from Gran Canaria. 

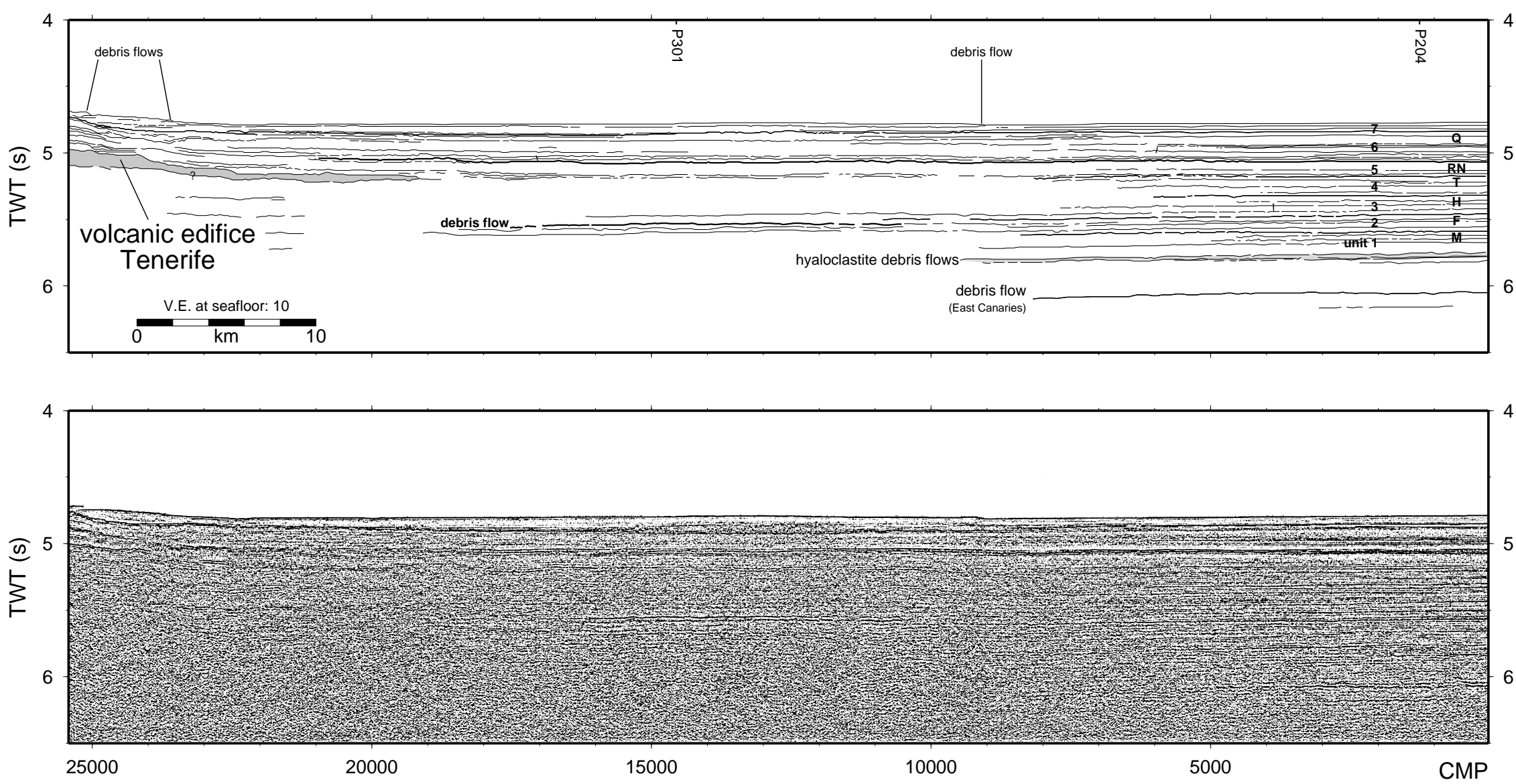

Figure 8. Time-migrated seismic section and line drawing for Line 205, which is radial to the Anaga massif on northeast Tenerife and runs through the volcanic apron north of Gran Canaria (Fig. 2). 
The debris flow from the East Canaries at a depth of $6050 \mathrm{~ms}$ TWT fades out to the southwest (CMP 8000), as well as the southwestward thinning hyaloclastite unit (lithologic Unit VII at Site 953).

\section{Line 130}

The remaining two profiles to be described are located in the channel between Gran Canaria and Fuerteventura. It is necessary to include the channel in a description of the northern apron, because it has influenced the shape of the island flank of Gran Canaria and the sedimentation in the northern apron. Line 130 (Fig. 9) represents a complete cross section through the channel (Fig. 2). The profile has a southwest-northeast direction and crosses the Amanay Bank, which is the most prominent feature on the profile. The plateau of the Amanay Bank is roughly $12 \mathrm{~km}$ in diameter and $60 \mathrm{~m}$ deep. The bank is connected with the southern edifice of Fuerteventura (Fig. 2), which is characterized by erosion lasting 14 m.y. (Coello et al., 1992). The slope of the flank of the Amanay Bank is up to $24^{\circ}$. Debris from the eroded surface has been deposited in prograding clinoforms on the southwestern edge of the plateau.

The volcanic basement on Line 130 is formed by Fuerteventura (Amanay Bank) in the northeast, with the younger shield of Gran Canaria onlapping the flank of Fuerteventura from the west up to CMP 17000, where the increased slope of the Amanay Bank prevented further transport of products from Gran Canaria. The surface of the shield of Gran Canaria shows a distinct hilly relief with a typical wavelength between 1 and $3 \mathrm{~km}$.

A large portion of the rough volcanic basement relief between Gran Canaria and Fuerteventura is covered with sediments. The channel between CMP 2500 and 6000 shows very complex infill structures caused by the interaction of high energy sedimentary input from Gran Canaria, erosion, and bottom currents. Strong bottom currents were caused by the reduction of the cross section between the islands, when the volcanic basement formed an only $1550 \mathrm{~m}$ deep barrier. The erosional channel at the toe of the southwestern flank of the Amanay Bank is caused by the diversion and strengthening of the currents around the southwestern tip of Fuerteventura.

The sediments between CMP 8000 and 16500, show in most parts, well-stratified infill patterns with parallel to divergent or wavy reflection configurations. The amplitudes are generally high, and the continuity is excellent. In the lower part of the sequence some faults have developed with vertical displacements of $<5 \mathrm{~m}$, whereas erosion has influenced the upper part of the sequence, especially close to the Amanay Bank. Because of the isolated location of the sedimentary infill structure, it is impossible to correlate any reflector directly into the apron north or south of Gran Canaria. Nevertheless, there are some consistencies in the vertical spacing of reflectors between this area and around Site 953, which suggest that the infill started at $\sim 10$ Ma.

The sediments northeast of the Amanay Bank have been influenced by mass wasting from the bank as well as from the southern part of Fuerteventura, whose flank is dipping perpendicular to the seismic line. Input from Gran Canaria is shielded by the Amanay Bank.

\section{Line 133}

Line 133 (Fig. 10) is also located in the channel between Gran Canaria and Fuerteventura (Fig. 2). The northwestern end of the profile crosses the submarine ridge offshore La Isleta, whereas the southeastern end lies in the stratified sedimentary basin discussed above for Line 130. The submarine ridge of La Isleta has a slope of up to $24^{\circ}$ and is covered with a sequence of some $100 \mathrm{~ms}$ TWT thick detritus with low amplitudes, discontinuous reflectors, and a contorted configuration. The erosional channel between CMP 10000 and 12000 is filled with some detritus and three slide blocks, which are some
$700 \mathrm{~m}$ wide and $60 \mathrm{~m}$ high. The channel can be traced basinward where it crosses Line 134.

Between CMP 10000 and 4000, the volcanic basement shows three elevated features, which are interpreted as part of a submarine volcanic complex. The two elevations at CMP 7000 and 4800 represent volcanic cones, the latter one with a slope of $30^{\circ}$ and an elevation of $840 \mathrm{~m}$ above the adjacent basement. The elevation at CMP 9000 does not have a typical cone shape on the seismic image, but might be a volcanic cone as well, possibly located out of the line.

Sediments with a chaotic reflection pattern were deposited at the base of the erosional channel to the east of the volcanic complex (between CMP 3600 and 4400). The sedimentary sequence southeast of the channel thins toward the channel, indicating the influence of currents, which must have originated, or at least noticeably strengthened, after the buildup of the volcanic complex. Exact age correlation of the sediments on this line is not possible. However, taking the thickness of the sediments into account, which are influenced by the channel currents, and assuming sedimentation rates similar to those in the apron, currents must have been active since at least $5 \mathrm{Ma}$, which gives the minimum age of the volcanic complex. The two cuts into the upper part of the sedimentary sequence $~ C M P ~ 2400$ and 400 represent erosional truncations, eroding the sediments which tower above the surrounding basement structures. This indicates that bottom currents occur in the entire channel between Gran Canaria and Fuerteventura.

The sediment unit covers two basement elevations at CMP 1500 and 400 . Several reflectors of the surrounding sediments cross these basement structures. This three-dimensional effect indicates that the features are surrounded by sediments. They are either volcanic cones (completely surrounded by sediments) or tips of ridges (partly surrounded by sediments). With regard to the nearby cones to the west, a cone shape seems to be more likely.

\section{MAPPING OF THE VOLCANIC APRON}

Mapping of the prominent reflectors and seismic units contributes to the understanding of the three-dimensional structure of the apron. The conversion from TWT to depth was done by a smoothed velocitydepth function for Site 953 assuming a linear increase of velocity with depth $\left(v=v_{0}+c z\right.$, with $v_{0}$ the velocity at $0 \mathrm{mbsf}, c$ the velocity increase, and $z$ the depth below seafloor). The best fit was achieved with $c=1.22 \mathrm{~s}^{-1}$ and $v_{0}=1532 \mathrm{~ms}^{-1}$. The relation between $z$ and $T W T$ is given by $z=v_{0} / c \cdot\left(\mathrm{e}^{\mathrm{c} \cdot T W T / 2}-1\right)$, that is $\left.z[\mathrm{mbs}]=1256 \cdot\left(\mathrm{e}^{0.00061 \cdot T W T[\mathrm{~ms}}\right]-1\right)$. This relation is plotted together with the original data (derived from physical properties and downhole logging velocities) in Figure 11 and is used as the regional velocity function in the apron north of Gran Canaria. Lateral velocity changes are not considered, but comparison with Site 954 shows that the deviations are $<5 \mathrm{~m}$.

\section{The Submarine Island Flanks}

The submarine flanks of Gran Canaria, Tenerife, and Fuerteventura are represented in the northern apron of Gran Canaria. The top of the massive island flanks is the most remarkable feature in the reflection seismic lines because of the mostly strong reflection amplitude and the unconformable contact with the overlying units with numerous baselaps.

Lithologic Unit IV at Site 953 (Fig. 3) is interpreted to represent the thin outermost flank of the shield volcano of Gran Canaria. The age of the unit is middle Miocene, $15 \mathrm{Ma}$, indicating a rapid growth of the shield because subaerial volcanism started around the same time. The feathered edge of the flank of Fuerteventura (Amanay Bank) lies stratigraphically just below the penetration depth at Site 953. The biostratigraphy (Schmincke, Weaver, Firth, et al., 1995) gives a minimum age of $15.8 \mathrm{Ma}$ for the bottom of the drill hole; the 

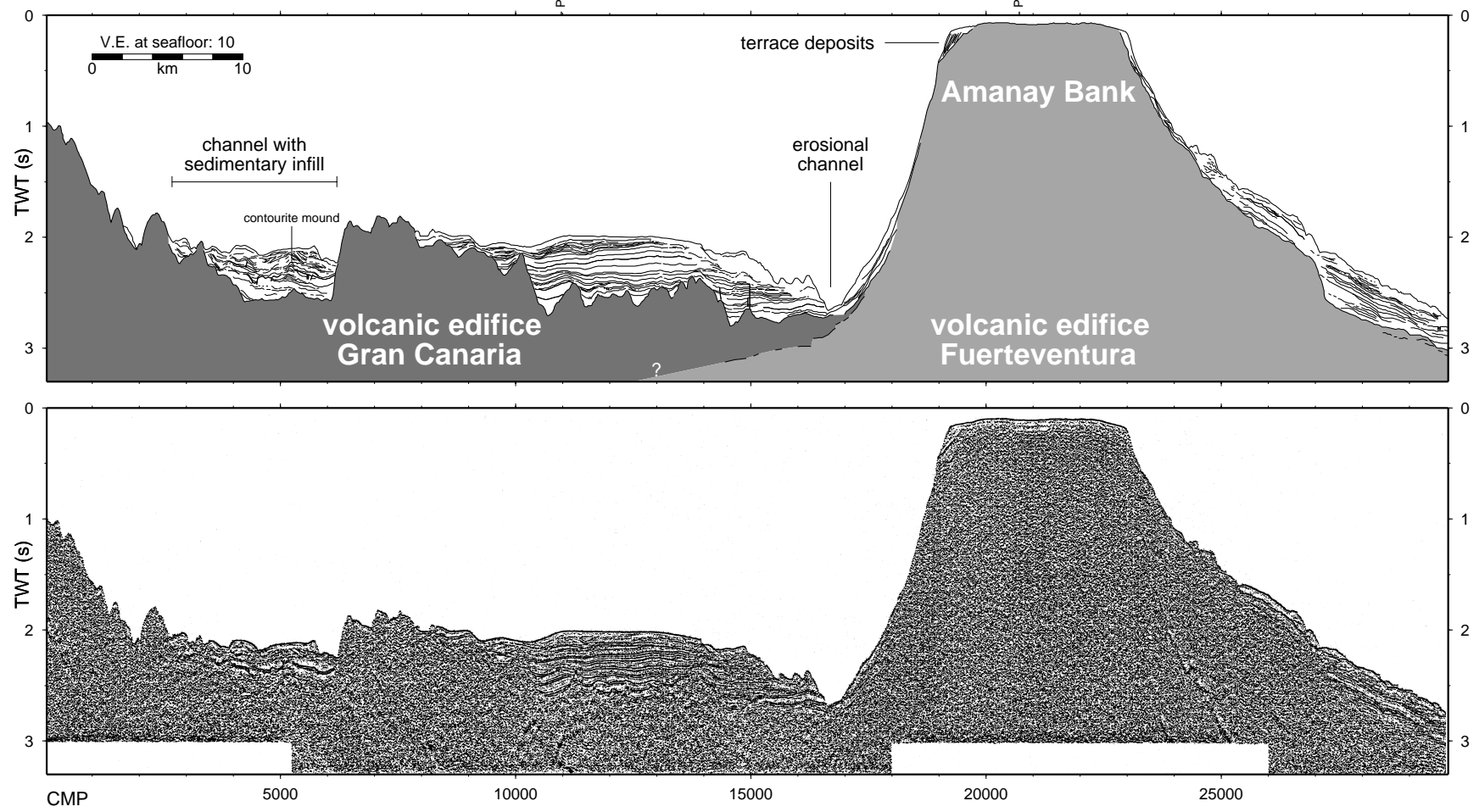

Figure 9. Time-migrated seismic section and line drawing for Line 130, which is located in the channel between Gran Canaria and Fuerteventura (Fig. 2).

maximum age is 17.4 Ma. The age of the submarine part of southern Fuerteventura therefore can be estimated between 16 and $18 \mathrm{Ma}$, fitting with the maximum K-Ar age of $15.8 \mathrm{Ma}$ (Coello et al., 1992) at the subaerial southern edifice of Fuerteventura. The submarine flank of northeast Tenerife is interbedded in the sedimentary basin northwest of Gran Canaria (Fig. 8) at a stratigraphic position of $\sim 6 \mathrm{Ma}$.

The temporal succession of the submarine shield stages of the islands-Fuerteventura as the oldest, followed by Gran Canaria and Tenerife - has influenced the shape of the individual island shields (Funck et al., 1996). The building of Fuerteventura to the west was into the open ocean; no preexisting islands could influence the deposition of the volcanic material. Gran Canaria, however, had to its east the shield of Fuerteventura, hampering the growth of the shield toward that direction. This effect can be well seen in Figure 12, which shows the depth of the submarine island flanks. The growth of Gran Canaria began approximately at the end of the shield-building phase of the southern edifice of Fuerteventura. Volcanic material deposited to the east of Gran Canaria had to be transported uphill at the southwestern flank of Fuerteventura, causing a ponding of the Gran Canaria shield against the submarine flank of Fuerteventura. This ponding can be seen on seismic Line 130 (Fig. 9), located between the two islands, and in the gentle dip of the Gran Canaria flank toward the east compared to the uninfluenced north (Fig. 12). The limited eastern depositional space was filled up until the material reached the steep flank of Fuerteventura. This depositional barrier diverted the volcanic deposits to the north and the south. The northward diversion can be seen in Figure 12, where the isolines north of Gran Canaria are not radially symmetric, but extend northward when moving to the east.

The western part of the Gran Canaria shield grew into the open ocean, limiting the depositional space for the later emerging island of Tererife. This resembles the relation between Fuerteventura and Gran Canaria, namely a ponding of the Tenerife deposits against the flank of Gran Canaria. The main difference is that the area of the later chan- nel between Gran Canaria and Tenerife was filled with pelagic sediments and volcaniclastics from Gran Canaria for some $8 \mathrm{~m}$.y. before the growth of Tenerife, whereas there was almost no gap between the shield-building stages of Fuerteventura and Gran Canaria.

In general, volcanic flanks overlain by younger shields could not be detected because of the relatively weak acoustic source in the seismic system used during the Meteor 24 survey. That is the reason why the extent of the western flanks of Gran Canaria and Fuerteventura cannot be mapped completely: they are partially masked by the younger flanks of the adjacent western island.

The depths of the feathered edges of the island flanks in the northern basin are $\sim 4750 \mathrm{~m}$ for Fuerteventura, between 4500 and $4600 \mathrm{~m}$ for Gran Canaria, and $4000 \mathrm{~m}$ for Tenerife. The flank of Gran Canaria extends some $60 \mathrm{~km}$ seaward in the northern basin, to the east its edge is closest to the shore $(44 \mathrm{~km})$, where the growth of the shield was limited by the preexisting shield of Fuerteventura. The extent of the flank of Fuerteventura is $85 \mathrm{~km}$ from the shoreline, or $\sim 50 \mathrm{~km}$ from the plateau of the Amanay Bank. Tenerife extends $\sim 50 \mathrm{~km}$ to the northeast.

\section{Quaternary Seismic Unit 7}

Seismic Unit 7 comprises the sedimentary sequence between the seafloor and reflector Q, that is, the last $0.8 \mathrm{~m}$.y. Reflector Q as the lower boundary layer can be correlated up to $34 \mathrm{~km}$ toward Gran Canaria and Tenerife, and as close as $25 \mathrm{~km}$ to the Amanay Bank. The low volcaniclastic input from the Amanay Bank results in a less distinctive slope facies, and therefore correlation is possible even in more proximal distances.

Figure 13 shows the thickness of seismic Unit 7, which varies between 30 and $65 \mathrm{~m}$. The thick black line marks the position of the downlap of a debris flow from Tenerife on the seafloor, identified on Profiles 202 and 205 (Fig. 8). The thickness of Unit 7 decreases here by some $10 \mathrm{~m}$. The area covered by the debris flow is at least 800 

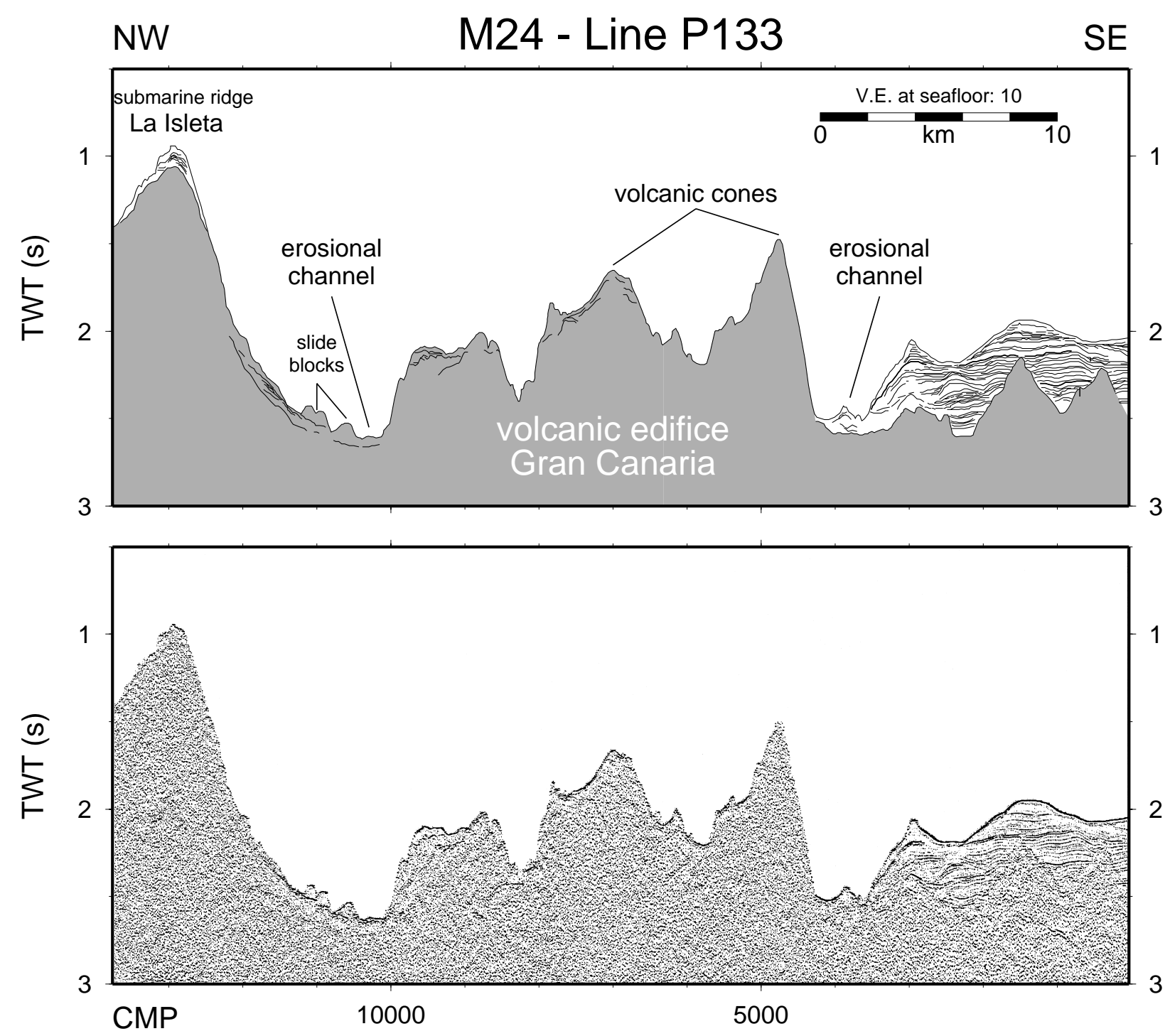

Figure 10. Time-migrated seismic section and line drawing for Line 133, located in the northern entrance of the channel between Gran Canaria and Fuerteventura (Fig. 2).

$\mathrm{km}^{2}$, so that the minimum volume of the flow is $\sim 8 \mathrm{~km}^{3}$. Further to the east, the thickness of seismic Unit 7 increases again to $65 \mathrm{~m}$ on Profile 135, where a number of debris flows from Fuerteventura (including the Amanay Bank) have thickened the unit.

\section{Sedimentation Rates}

With the thickness of the seismic units, sedimentation rates can be computed by means of the ages given by the bio- and magnetostratigraphy at Site 953 (Brunner et al., Chap. 9, this volume). These rates are not corrected for compaction. The porosities at Site 953 can give an idea about the amount of compaction. They are $\sim 65 \%$ close to the mudline and $\sim 50 \%$ above the island flank (Schmincke, Weaver, Firth, et al., 1995). This corresponds to a compaction of some $30 \%$. The computation of the sedimentation rates is made on the assumption that the upper and lower boundaries of the unit are of the same age throughout the area. This assumption is justified because the reflectors represent thin individual mass-flow units.

The minimum sedimentation rates were observed in seismic Unit 4 (Fig. 14), where they vary between 3 and $4 \mathrm{~cm} / \mathrm{k}$.y. Unit 4 (5.3-9.5
Ma) roughly corresponds to the volcanic hiatus on Gran Canaria. This gives the comparatively low sedimentation rates because of the decrease of volcaniclastic input into the sedimentary basin. Close to Site 953 , the unit has a maximum thickness of up to $170 \mathrm{~m}$ (i.e., a sedimentation rate of $>4 \mathrm{~cm} / \mathrm{k} . \mathrm{y}$.), formed by a mound in the upper part of the unit. The mapped area of the unit is restricted to the northeastern part of the apron. This is caused by the mentioned westward decrease of reflectivity in the apron (see Line 205, Fig. 8), which influenced the boundary reflectors of the unit. The landward limit is determined by the transition from the basin to the more chaotic slope facies, where the reflectors cannot be correlated.

The maximum sedimentation rates of the mapped seismic Units 2 through 7 were observed in Unit 2 (Fig. 15). The sedimentation rate and thickness of Unit 2 increases from the northeast toward Gran Canaria. In the northeast, where the uplift structure observed on Profile 203 (Fig. 5) is responsible for the thinning, the sedimentation rate is as low as $4 \mathrm{~cm} / \mathrm{k} . \mathrm{y}$. Close to Site 953 , the lower boundary reflector of the unit (reflector M, 13.9 Ma) onlaps the flank of Gran Canaria, and here the unit is $\sim 230 \mathrm{~m}$ thick, resulting in a sedimentation rate of $11 \mathrm{~cm} / \mathrm{k} . \mathrm{y}$. Responsible for this high rate are both the high volcani- 


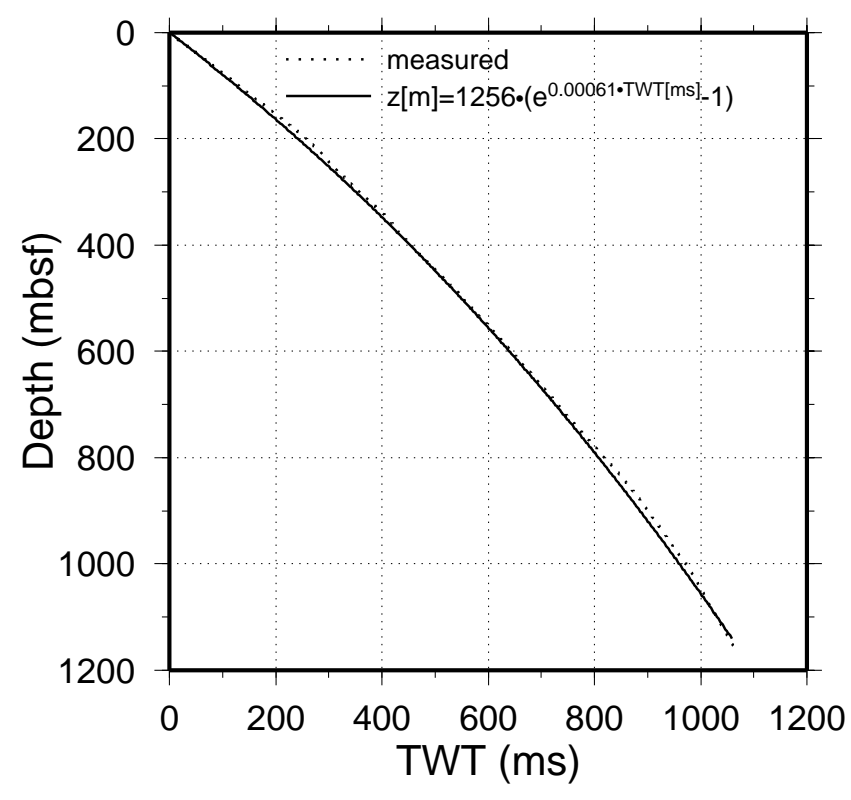

Figure 11. Relation between TWT and depth below seafloor at Site 953. The dotted line $=$ original data (physical properties and downhole logging velocities), and the solid line = best fit to the data assuming a linear increase of velocity with depth.

clastic input during the Mogan phase of volcanism, and the flexure of the lithosphere as response to the volcanic load of Gran Canaria. The flexure caused a local depression along the outer rim of the island flank, which was subsequently a preferred area of deposition until the low was filled.

Sedimentation rates in the other units reflect the volcanic activity on Gran Canaria in a similar way, that is, lower volcanic activity results in low volcaniclastic sediment supply and, consequently, in low sedimentation rates.

\section{DISCUSSION}

\section{Mass Wasting}

Mass wasting is the main mechanism for the deposition of volcaniclastic deposits in volcanic aprons around ocean islands. This includes slides (slumps and debris avalanches) and debris flows, which may turn into turbidity currents under appropriate hydrodynamic conditions. Moore et al. (1989) use the following distinction between slumps and debris avalanches: slumps are slow moving, wide, and thick with transverse blocky ridges and steep toes, whereas debris avalanches are fast moving, long (compared to width), and thinner. They commonly have a well-defined amphitheater at their head and hummocky terrain in the lower part. In case of the Hawaiian Islands, as many as 68 landslides $>20 \mathrm{~km}$ long are known (Moore, Normark, et al., 1994), contrasting with the only three major slides at the Canary Islands documented so far. Two of these slides occurred at Hierro (Holcomb and Searle, 1991; Masson et al., 1992; Masson, 1996), and one slide at the north flank of Tenerife (Watts and Masson, 1995). The identification of the slides at both island archipelagos is primarily based on surface features, which were detected by means of the side-scan sonar system GLORIA (e.g., Moore et al., 1989). The reason for the comparatively small number of slides documented at the Canaries might be because of the high sedimentation rates, which mask earlier slides. In contrast, background sedimentation rates are low at the Hawaiian Islands, and, hence, slide deposits remain visible at the seafloor for a longer time than at the Canaries. Older slides can only be detected by drilling and seismic investigations in the aprons surrounding the islands. Both methods are relatively laborious compared to the GLORIA system, by which large areas can be mapped in a short time.

Nevertheless, drilling into the apron south of Gran Canaria in 1976 has already proved the presence of several meters thick Miocene volcaniclastic debris flows (von Rad, Ryan, et al., 1979). Leg 157 and the seismic data of the presite survey detected new masswasting events in the apron north of Gran Canaria, of which the most important are presented below.

\section{The 12-Ma Debris Flow}

The mass-wasting event probably best documented by the new data is the basaltic breccia of lithologic Unit IV at Site 954. An isopach map of this unit was computed by measuring the TWTs between the top and base reflector and applying a velocity of $5.0 \mathrm{~km} / \mathrm{s}$, found to be the average velocity of the unit at Site 954 (Schmnincke, Weaver, Firth, et al., 1995). To the north, the thickness increases to $>80 \mathrm{~m}$ on Line 205. The northward limit of the deposits is out of the seismic net, and to the south, the basaltic debris flow cannot be distinguished from the similar basaltic island flank. The volume of the deposits was calculated for the mapped area in Figure $16\left(909 \mathrm{~km}^{2}\right)$, resulting in $58.5 \mathrm{~km}^{3}$ of material. This yields an average thickness of $64 \mathrm{~m}$. Regarding the fact that the thickest portions of the debris flow are located in the north, where the seismic lines stop, several tens of cubic kilometers more of material associated with the mass-wasting event can be expected.

The lateral east-west extension of the unit mapped on Lines 210, 202, and 205 suggests an origin at the northern flank of Gran Canaria, most probably at the indentation of the northern coast and shelf. This indentation is thought to be a slide scar, forming the amphitheater from which the basaltic material advanced $>70 \mathrm{~km}$ into the volcanic apron. The exact shape of the amphitheater is difficult to determine, because the Quaternary volcanism on the La Isleta peninsula in the east probably has changed its original shape. The bathymetric map of Figure 2 suggests an indentation of some $10-12 \mathrm{~km}$ width, cut $\sim 3 \mathrm{~km}$ into the island. Estimating the thickness of the slide block to be somewhere between 2 and $4 \mathrm{~km}$ yields a volume between 60 and $144 \mathrm{~km}^{3}$, which is in good accordance with the measured (mapped) debris flow volume of $>58.5 \mathrm{~km}^{3}$. The amphitheater and the advance of the debris into distal areas of the apron along a relatively narrow path suggest a rapid emplacement of the deposits, possibly by a debris avalanche (following the definition of Moore et al., 1989).

\section{Hyaloclastite Debris Flow}

The most voluminous mass-wasting event detected in the apron north of Gran Canaria was the emplacement of lithologic Unit VII at Site 953, which consists of hyaloclastite debris flow and turbidite deposits (Schmincke, Weaver, Firth, et al., 1995). They were probably formed by shallow submarine eruptions of basaltic magma and were deposited by debris flows and high-concentration turbidity currents. Seismically, the unit is composed of a number of internal reflectors with medium to high amplitudes. To map the thickness of the hyaloclastite unit (Fig. 17), the TWTs were converted to depth by assuming a velocity of $3.5 \mathrm{~km} / \mathrm{s}$. The thickness reaches a maximum of slightly $<200 \mathrm{~m}$ in the vicinity of Site 953 . At Line 135 , the unit thins out when it onlaps onto the flank of the Amanay Bank. The northeastern extent was mapped on Lines 202 and 203, and the southwestern one on Lines 202 and 205. The correlation of the unit on Line 134 southwest of Site 953 was hampered by the thickening of the overlying shield of Gran Canaria. Nevertheless, the suspected limit on Line 134 fits well with the limits on Lines 202 and 205.

The patterns of the isopach map suggest the source of the mass flows somewhere on the (submarine) southern edifice of Fuerteventura. The flat onlap of the unit onto the flank of the Amanay Bank favors a source outside the bank, because otherwise remnants of the 
Figure 12. Depths of the island flanks of Gran Canaria, Fuerteventura, and Tenerife. Contour interval is $250 \mathrm{~m}$. Lines $=$ seismic profiles of Meteor Cruise 24 .

Figure 13. Isopach map of seismic Unit 7 (between seafloor and the 0.8-Ma reflector Q). Thin lines = seismic profiles of Meteor Cruise 24, and the bold line = extent of a young debris flow from Tenerife (indicated by arrows). The contour interval is $10 \mathrm{~m}$.

Figure 14. Sedimentation rates in seismic Unit 4 between the reflectors $\mathrm{H}$ and $\mathrm{T}$, roughly corresponding to the volcanic hiatus on Gran Canaria. Lines = seismic profiles of Meteor Cruise 24. The contour interval is $1 \mathrm{~cm} / \mathrm{k} . \mathrm{y}$.
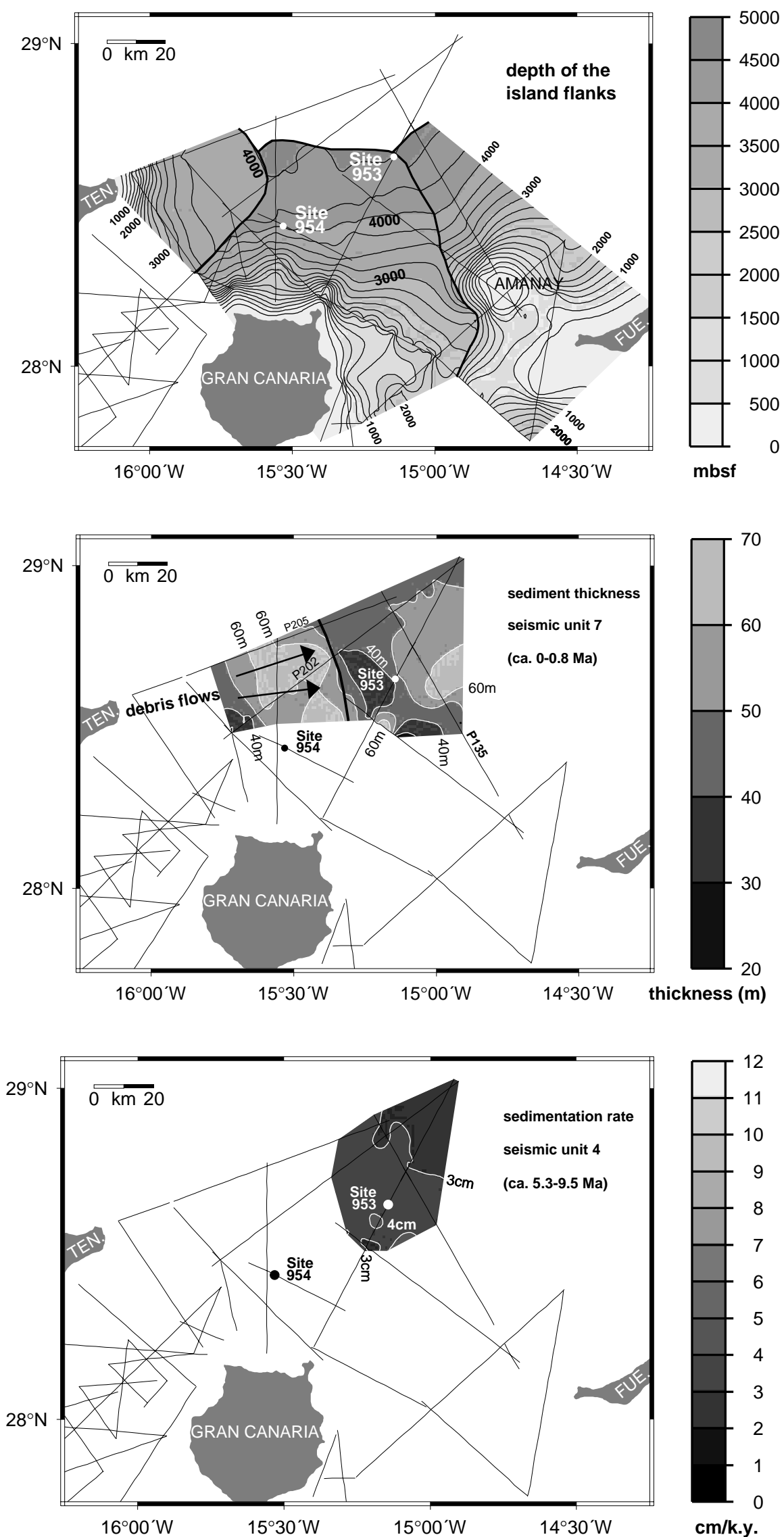

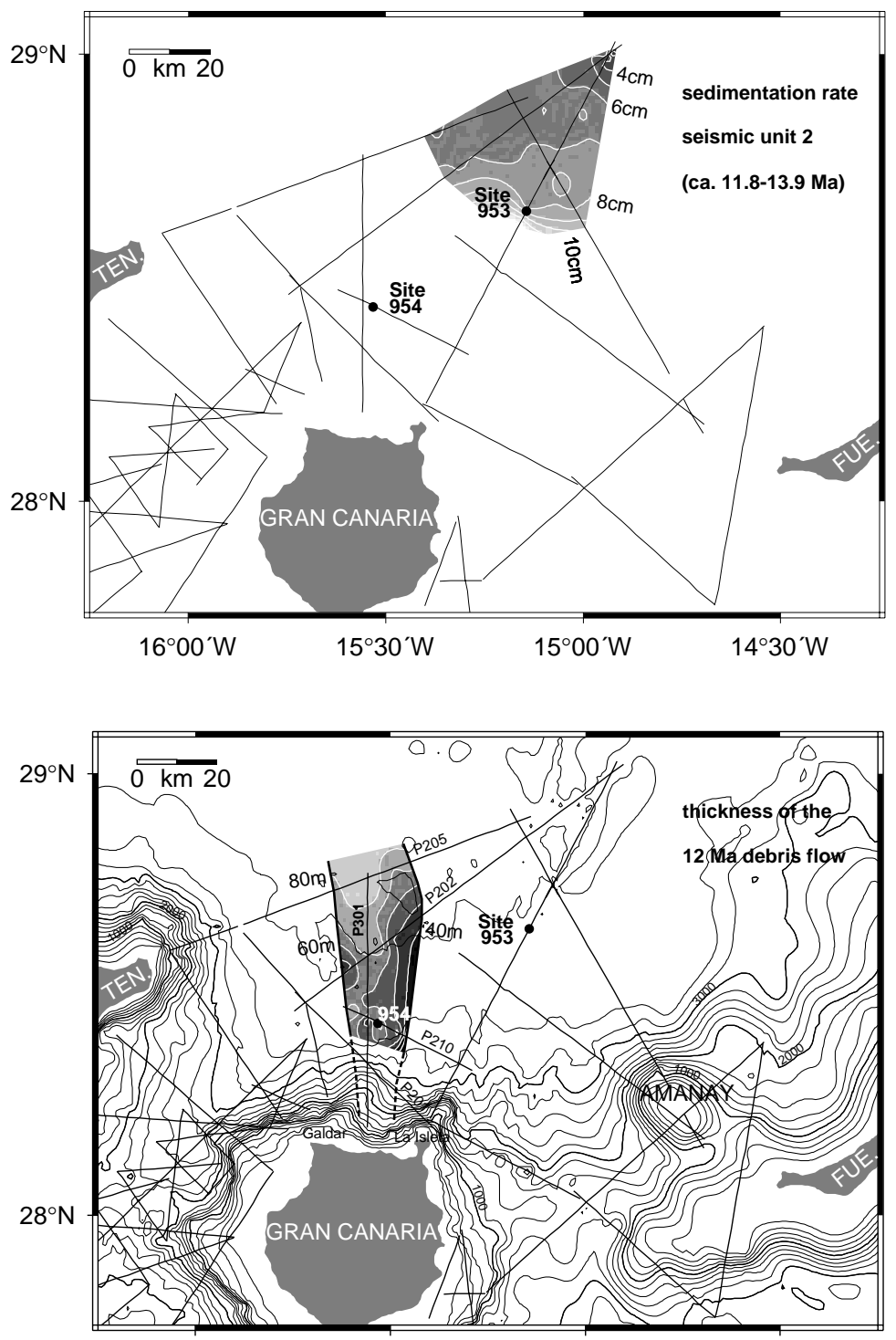

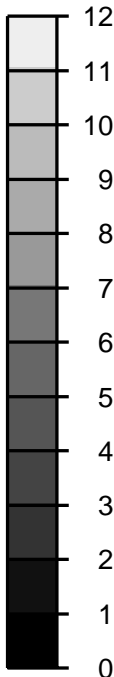

$\mathrm{cm} / \mathbf{k} . \mathbf{y}$.
Figure 15. Sedimentation rates in seismic Unit 2 between the reflectors $\mathrm{M}$ and $\mathrm{F}$ (Miocene volcanism on Gran Canaria, 13.9-11.8 Ma). Lines = seismic profiles of Meteor Cruise 24. The contour interval is $1 \mathrm{~cm} / \mathrm{k} . \mathrm{y}$. material would be expected further upslope and the reflection patterns would possibly be more chaotic. H.-U. Schmincke (pers. comm., 1995) concludes from the petrographic-geologic succession at Sites 953 and 956, that the main source of the hyaloclastite unit was Gran Canaria; only the lower part is interpreted to be possibly from Fuerteventura. The interpretation of Schmincke does not agree well with the contour lines (Fig. 17).

From the area mapped in Figure 17, the volume of the hyaloclastite unit was computed: the area is $1162 \mathrm{~km}^{2}$, the average thickness is $78 \mathrm{~m}$, and the volume is $90 \mathrm{~km}^{3}$. Because a large portion of the material was deposited outside the seismic net, the total amount is much higher than the mapped $90 \mathrm{~km}^{3}$, possibly twice as high.

\section{East Canary Debris Flow}

A third conspicuous mass-wasting event is the strong reflector band seen on Profiles 203 and 205 (Figs. 5, 8), located stratigraphically below the maximum penetration at Site 953 . The thinning and termination of the flow to the west suggest an origin on the East Canaries. The present dip of the debris flow is to the south, in contrast to the more southwesterly dips of the overlying sediments up to reflector M. This change in dip may be caused by the flexure of the lithosphere because of the volcanic load of Fuerteventura. The flow was likely emplaced $\sim 20$ Ma during the rapid shield-building of the central edifice of Fuerteventura (Coello et al., 1992). Alternatively, the debris flow unit may consist of shallow submarine volcaniclastics from the basal complex of Fuerteventura of Oligocene age.

\section{Other Volcaniclastic Interbeds}

Other volcaniclastic interbeds in the apron are not thick enough to allow seismic separation of their top and base. But their individual volumes can easily reach several cubic kilometers. The lapillistones forming the reflector RN are at least $2 \mathrm{~m}$ thick, both at Site 953 and 954 (Schmincke, Weaver, Firth, et al., 1995). The area in which the reflector can be correlated covers some $3500 \mathrm{~km}^{2}$, resulting in a volume of $7 \mathrm{~km}^{3}$, without taking into account the volumes in the chaotic slope facies and north of the seismic net. Because of the low core recovery in that interval, most likely because of the coarse grained nature of the lapillistones, the real thickness may be up to $8 \mathrm{~m}$ at Site 953 and possibly $20 \mathrm{~m}$ at Site 954 . The real volumes may thus be in excess of $50 \mathrm{~km}^{3}$.

\section{Origin of Volcaniclastic Sediments}

The origin of the volcaniclastic sediments in the basin investigated north of Gran Canaria can be roughly subdivided into three groups (ignoring the proximity to the island flanks of Gran Canaria, 
Figure 17. Isopach map of the hyaloclastite unit drilled as lithologic Unit VII at Site 953. The contour interval is $25 \mathrm{~m}$ for the hyaloclastites and $200 \mathrm{~m}$ for the bathymetry. Lines $=$ seismic profiles of Meteor Cruise 24.

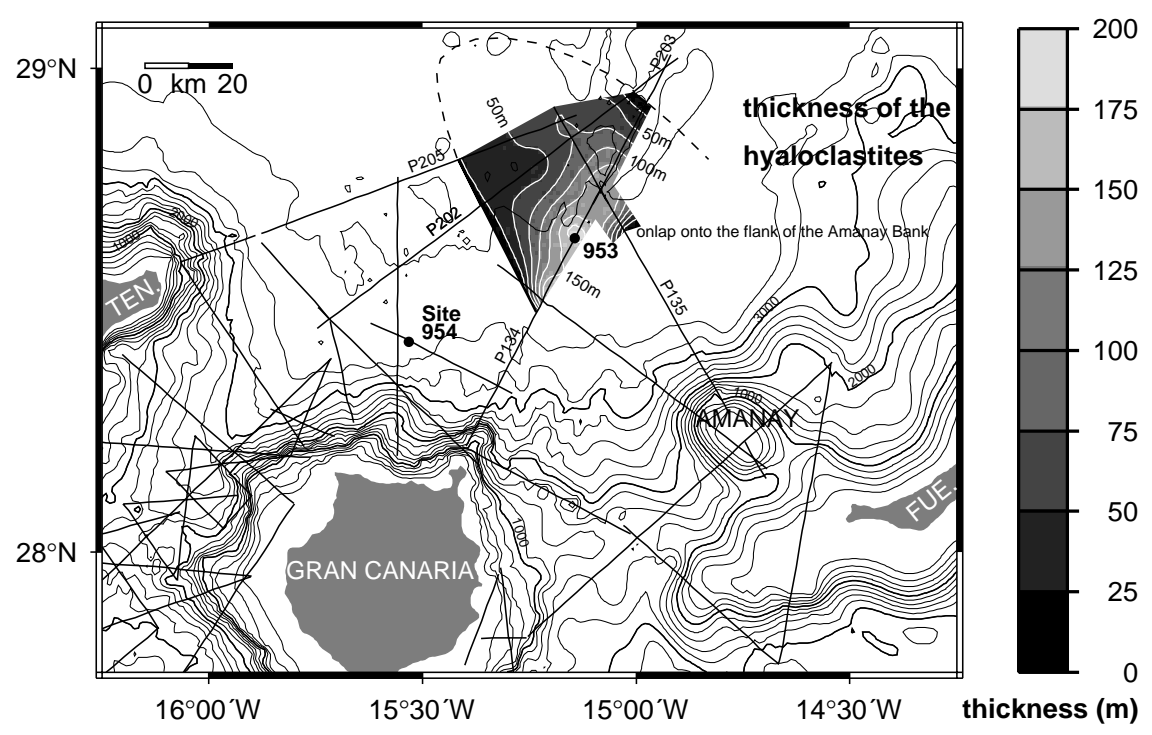

latter channel is interpreted to be largely because of the greater water depth and the more funnel-like shape. Figure 2 shows the funnelshaped isobaths with a water depth of $2250 \mathrm{~m}$. The channel between Gran Canaria and Fuerteventura in contrast forms a more or less horizontal barrier between the islands with a maximum depth of only $1550 \mathrm{~m}$. This enormous reduction of the cross section increases the flow velocity.

Almost the entire channel between Gran Canaria and Fuerteventura is influenced by bottom currents. Sediments are deposited in basement lows, but they are affected by erosional currents as soon as they tower above the surrounding volcanic basement (Fig. 10).

Erosional activity is not a stationary process, new channels are formed, and the flow velocity in existing channels can change. The emergence of the volcanic cones on Profile 133 (Fig. 10) has certainly caused a strengthening of the bottom currents and enforced the formation of the two flanking erosional channels.

The conspicuous channel on Line 130 (Fig. 9), where the shield of Gran Canaria onlaps the steep flank of the Amanay Bank, is caused by strong currents around the southwestern tip of Fuerteventura. On Profile 132, somewhat more to the south (Fig. 2), a similar erosional channel is visible at the toe of the flank of Fuerteventura. On the northern Profile 136 this current is also active. In the younger part of the influenced sedimentary sequence, the current is characterized by erosive activity, whereas the lower part between reflectors $\mathrm{RN}$ and $\mathrm{H}$ shows contourites, indicating somewhat lower flow velocities during that time interval.

The Barranco de Guiniguada, a canyon on northeast Gran Canaria (Fig. 2), leads toward the channel, which can be correlated across Lines 133 (Fig. 10) and 134 (Fig. 4). In contrast to the onshore canyons in the south or the east, the Barranco de Guiniguada did not form a sedimentary apron when entering the sea. The bottom current system between Gran Canaria and Fuerteventura has transported the material further into the basin north of Gran Canaria. The present shape of the submarine channel thus probably represents a complex interaction between subaerial erosion of the canyon, erosion by the transport of debris down the submarine slope, and erosion by bottom currents, resulting in a wide and long channel, which has advanced some $40 \mathrm{~km}$ into the basin. The cross section of Line 133 (Fig. 10) shows that the channel is flanked by the submarine extent of the La Isleta peninsula to the west and by the volcanic cones to the east. This construction of the channel may have caused and directed the strong bottom currents, which prevent sedimentation in that channel on Line 133 except for some detritus and slide blocks. 


\section{CONCLUSIONS}

Reflection seismic profiling and drilling results of Leg 157 allowed a detailed analysis of the structure of the apron north of Gran Canaria. Not all features could be dated precisely, because the correlation of reflectors was difficult or impossible proximal to the islands, and below the maximum penetration depth of Site 953, no reliable stratigraphy is available. The temporal development and fill of the apron is summarized below.

With the buildup of the East Canary ridge, the region to the west was more or less shielded from sediment supply from Africa. A debris flow at a depth of $\sim 5.2 \mathrm{~km}$ is thought to be derived from the central edifice of Fuerteventura: the flow advanced $>100 \mathrm{~km}$ to the west. The change of the dip of the reflectors above and below the debris flow suggests a deposition during the crustal deformation because of the volcanic load of Fuerteventura, which is estimated to have taken place some time after the beginning of the subaerial volcanism (i.e., at $20-19 \mathrm{Ma}$ ), or during the formation of the basal complex in the Oligocene. The Amanay Bank is an eroded part of the southern shield of Fuerteventura, and its flank extends $\sim 50 \mathrm{~km}$ from the plateau into the apron down to a depth of $4750 \mathrm{~m}$.

A thick hyaloclastite unit onlaps the feathered edge of the flank of the Amanay Bank. The emplacement of the hyaloclastite debris flows and turbidites was somewhere between 15.8 and 17.4 Ma, and they were probably formed by shallow submarine eruptions of basaltic magma (Schmincke, Weaver, Firth, et al., 1995). Mapping of the thickness of the unit results in a total volume of $>90 \mathrm{~km}^{3}$ and suggests a source on the southern edifice of Fuerteventura. The maximum thickness is $\sim 200 \mathrm{~m}$.

Subsequent to deposition of the hyaloclastites, the volcanic shield of Gran Canaria was formed ( 14-16 Ma). To the east, the shield was ponded against the preexisting flank of Fuerteventura (Amanay Bank), forming a presently 1550-m-deep topographic barrier with a reduction of the cross-section, resulting in strong bottom currents with the formation of erosional channels. To the north, the flank extends $\sim 60 \mathrm{~km}$ seaward. Its depth at the outer rim is between 4500 and $4600 \mathrm{~m}$.

Reflector band M ( 13.9 Ma) represents an unconformity, dipping toward Gran Canaria, with almost horizontal layering of the overlying sediments. This unconformity is interpreted to have been caused by lithospheric flexure because of the load of Gran Canaria.

The sedimentation following the shield-building is characterized by intercalation of volcaniclastic interbeds and pelagic background sediments. Most of the volcaniclastic material came from Gran Canaria as mass flows or ash layers. The submarine ridge off Galdar has deflected volcaniclastic material from Gran Canaria to the northeastern part of the apron (low reflectivity in the western region), with the exception of the Pliocene Roque Nublo (RN) deposits. The corresponding reflector $\mathrm{RN}$ can be correlated across the entire northern survey area and represents $>7 \mathrm{~km}^{3}$ (probably $>50 \mathrm{~km}^{3}$ ) of lapillistones deposited to the north.

At $\sim 12 \mathrm{Ma}$, the northern flank of Gran Canaria collapsed, and $>60$ $\mathrm{km}^{3}$ (possibly $>100 \mathrm{~km}^{3}$ ) of volcaniclastic material formed basaltic debris flows, advancing $>70 \mathrm{~km}$ northward into the apron, where they are up to $80 \mathrm{~m}$ thick.

The shield of the Anaga massif on northeast Tenerife was rapidly formed at $\sim 6 \mathrm{Ma}$ and onlaps onto the older flank of Gran Canaria in the east. The depth of the Anaga shield is $4000 \mathrm{~m}$, and it extends some $50 \mathrm{~km}$ to the northeast, covering older sediments and masking them seismically.

Additional volcaniclastic input from Tenerife into the basin north of Gran Canaria occurred during the last $1 \mathrm{Ma}$. Widespread reflectors show the intense volcanic activity on Tenerife during this period, simultaneous with the Quaternary activity on northern Gran Canaria.
At the northern part of the barrier between Gran Canaria and Fuerteventura, a submarine volcanic complex with two volcanic cones is located, which seems to be older than $5 \mathrm{Ma}$ and has caused a reorientation and strengthening of the channel currents. The nearby subaerial Quaternary volcanism on La Isleta extends to the northeast, where a submarine volcano with several young lava flows has formed.

The seismic investigation of the apron in conjunction with the drilling data proved to be an effective method to reconstruct the volcanic islands' development by its deposits found in the apron, as well as enabling the geometry of the large submarine portions of the volcanic shield to be determined precisely. Slides and debris flows were detected seismically, whereas a study based only on surface features as in the Hawaiian Islands (Moore et al., 1989) would fail for most of the Canaries evolution, because the high sedimentation rates result in coverage of these features in a much shorter time period.

\section{ACKNOWLEDGMENTS}

We are grateful to Sebastian Krastel, Thomas Dickmann (both of GEOMAR), and Stig Berendt Marstal (University of Århus) for their assistance in the processing of the seismic data. We gratefully acknowledge Hans-Ulrich Schmincke and Roland Rihm (both of GEOMAR) for valuable discussions improving this paper. Tim Minshull and Rosemary Edwards reviewed an earlier version of the manuscript. We thank the crews and scientists of Meteor Cruise 24 and Leg 157 for staying several weeks on sea and collecting the seismic and drilling data. The work on this paper was supported by the Deutsche Forschungsgemeinschaft (DFG-Schm250/49 III GK, DFG-Schm250/54), the Bundesministerium für Forschung und Technologie and the European Union (EPOCH, EVSV-CT93-0283, and MAS2-CT94-0083).

\section{REFERENCES}

Ancochea, E., Fúster, J.M., Ibarrola, E., Cendrero, A., Coello, J., Hernín, F., Cantagrel, J.M., and Jamond, C., 1990. Volcanic evolution of the island of Tenerife (Canary Islands) in the light of new K-Ar data. J. Volcanol. Geotherm. Res., 44:231-249.

Brown, K.M., 1990. The nature and hydrogeologic significance of mud diapirs and diatremes for accretionary systems. J. Geophys. Res., 95:89698982.

Coello, J., Cantagrel, J.-M., Hernín, F., Fúster, J.-M., Ibarrola, E., Ancochea, E., Casquet, C., Jamond, C., Díaz de Turan, J.-R., and Cendrero, A., 1992. Evolution of the eastern volcanic ridge of the Canary Islands based on new K-Ar data. J. Volcanol. Geotherm. Res., 53:251-274.

Funck, T., 1996. Structure of the volcanic apron north of Gran Canaria deduced from reflection seismic, bathymetric and borehole data [Ph.D. dissert.]. Univ. Kiel.

Funck, T., Dickmann, T., Rihm, R., Krastel, S., Lykke-Andersen, H., and Schmincke, H.-U., 1996. Reflection seismic investigations in the volcaniclastic apron of Gran Canaria and implications for its volcanic evolution. Geophys. J. Int., 125: 519-536.

Fúster, J.M., Hernín, F., Cendrero, A., Coello, J., Cantagrel, J.M., Ancochea, E., and Ibarrola, E., 1993. Geocronología de la Isla de El Hierro (Islas Canarias). Bol. R. Soc. Hist. Nat. (Sec. Geol.), 88: 85-97.

García Cacho, L., Díez-Gil, J.L., and Araña, V., 1994. A large volcanic debris avalanche in the Pliocene Roque Nublo Stratovolcano, Gran Canaria, Canary Islands. J. Volcanol. Geotherm. Res., 63:217-229.

Hinz, K., Dostmann, H., and Fritsch, J., 1982. The continental margin off Morocco: seismic sequences, structural elements and geological development. In von Rad, U., Hinz, K., Sarnthein, M., and Seibold, E. (Eds.), Geology of the Northwest African Continental Margin: Berlin (Springer Verlag), 34-60.

Hoernle, K.A., and Schmincke, H.-U., 1993a. The petrology of the tholeiites through melilite nephelinites on Gran Canaria, Canary Islands: crystal fractionation, accumulation, and depths of melting. J. Petrol., 34:573597. 
, 1993b. The role of partial melting in the 15-Ma geochemical evolution of Gran Canaria: a blob model for the Canary Hotspot. J. Petrol., 34:599-627.

Holcomb, R.T., and Searle, R.C., 1991. Large landslides from oceanic volcanoes. Mar. Geotechnol., 10:19-32.

Holik, J.S., Rabinowitz, P.D., and Austin, J.A., Jr., 1991. Effects of Canary hotspot volcanism on structure of oceanic crust off Morocco. J. Geophys. Res., 96:12039-12067.

Klitgord, K.D., and Schouten, H., 1986. Plate kinematics of the central Atlantic. In Vogt, P.R., and Tucholke, B.E. (Eds.), The Geology of North America (Vol. M): The Western North Atlantic Region. Geol. Soc. Am., 351-378.

Le Bas, M.J., Rex, D.C., and Stillman, C.J., 1986. The early magmatic chronology of Fuerteventura, Canary Islands. Geol. Mag., 123:287-298.

Masson, D.G., 1996. Catastrophic collapse of the volcanic island of Hierro $15 \mathrm{ka}$ ago and the history of landslides in the Canary Islands. Geology, 24:231-234.

Masson, D.G., Kidd, R.B., Gardner, J.V., Huggett, Q.J., and Weaver, P.P.E., 1992. Saharan Continental Rise: sediment facies distribution and sediment slides. In Poag, C.W., and de Graciansky, P.C. (Eds.), Geologic Evolution of Atlantic Continental Rises: New York (Van Nostrand Reinhold), 327-343.

McDougall, I., and Schmincke, H.-U., 1977. Geochronology of Gran Canaria, Canary Islands: age of shield-building volcanism and other magmatic phases. Bull. Volcanol., 40:1-21.

Mehl, K.W., 1993. Structure and emplacement of the Pliocene Roque Nublo debris avalanche deposit, Gran Canaria, Spain.[Ph.D. thesis]. Ruhr-Univ. Bochum.

Moore, J.G., Clague, D.A., Holcomb, R.T., Lipman, P.W., Normark, W.R., and Torresan, M.E., 1989. Prodigious submarine landslides on the Hawaiian Ridge. J. Geophys. Res., 94:17465-17484.

Moore, J.G., Normark, W.R., and Holcomb, R.T., 1994. Giant Hawaiian landslides. Annu. Rev. Earth Planet. Sci., 22:119-144.

Roest, W.R., Dañobeitia, J.J., Verhoef, J., and Collette, B.J., 1992. Magnetic anomalies in the Canary Basin and the Mesozoic evolution of the central North Atlantic. Mar. Geophys. Res., 14:1-24.

Schmincke, H.-U., 1976. The geology of the Canary Islands. In Kunkel, G. (Ed.), Biogeography and Ecology in the Canary Islands: The Hague (W. Junk), 67-184.
, 1982. Volcanic and chemical evolution of the Canary Islands. In von Rad, U., Hinz, K., Sarnthein, M., and Seibold, E. (Eds.), Geology of the Northwest African Continental Margin: Berlin (Springer), 273-306.

, 1994. Geological Field Guide: Gran Canaria (7th ed.): Kiel, Germany (Pluto Press).

Schmincke, H.-U., and Rihm, R., 1994. Ozeanvulkan 1993, Cruise No. 24, 15 April-9 May 1993. METEOR-Berichte, Univ. Hamburg, 94-2.

Schmincke, H.-U., Weaver, P.P.E., Firth, J.V., et al., 1995. Proc. ODP, Init. Repts., 157: College Station, TX (Ocean Drilling Program).

Verhoef, J., Collette, B.J., Dañobeitia, J.J., Roeser, H.A., and Roest, W.R., 1991. Magnetic anomalies off west Africa $\left(20^{\circ}-38^{\circ} \mathrm{N}\right)$. Mar. Geophys. Res., 13:81-103.

von Rad, U., Ryan, W.B.F., et al., 1979. Init. Repts. DSDP, 47 (Pt. 1): Washington (U.S. Govt. Printing Office).

Watts, A.B., 1994. Crustal structure, gravity anomalies and flexure of the lithosphere in the vicinity of the Canary Islands. Geophys. J. Int., 119:648-666.

Watts, A.B., and Masson, D.G., 1995. A giant landslide on the north flank of Tenerife, Canary Islands. J. Geophys. Res., 100:24487-24498.

Watts, A.B., Peirce, C., Collier, R., Dalwood, R., Canales, J.P., and Henstock, T.J., 1997. A seismic study of the Canary Islands: implications for volcano growth, lithospheric flexure and magmatic underplating. Earth Planet. Sci. Lett., 146:431-447.

Whelan, J.K., 1979. $C_{1}$ to $C_{7}$ hydrocarbons from IPOD Holes 397 and 397A. In von Rad, U., Ryan, W.B.F., et al., Init. Repts. DSDP, 47 (Pt. 1): Washington (U.S. Govt. Printing Office), 531-539.

Wissmann, G., 1979. Cape Bojador slope, an example for potential pitfalls in seismic interpretation without the information of outer margin drilling. In von Rad, U., Ryan, W.B.F., et al., Init. Repts. DSDP, 47 (Pt. 1): Washington (U.S. Govt. Printing Office), 491-499.

Date of initial receipt: 24 June 1996

Date of acceptance: 29 January 1997

Ms 157SR-101 